\title{
Thomas COOMANS
}

\section{"Unexpected Connections: The Benedictine Abbey of Maredsous and Christian Architecture in China, 1900-1930s"}

Revue Bénédictine, vol. 131, fasc. 1, June 2021, p. 264-291 (text), 292299 (figures)

Print ISSN: 0035-0893 / Online ISSN: 2295-9009

Direction and administration: Abbaye de Maredsous (Belgium)

Digital edition: BREPOLS Online https://doi.org/10.1484/J.RB.5.124394

\section{ABSTRACT}

Recent research has revealed that the Benedictine abbey of Maredsous exerted significant but conflicting influences on missionary architecture in China through two different channels. These influences were by no means the result of a strategy pursued by the abbey of Maredsous. After having introduced the interwoven Belgian and Benedictine missionary networks in China, this article focuses on the two architectural connections of Maredsous in China. First, the missionary-architect Father Alphonse De Moerloose, who was not a Benedictine but a Scheut Father; he exported the Gothic Revival style of Augustus Pugin and Baron Bethune to northern China in the years 1900-29 and referred to the abbey church of Maredsous for his major projects. Second, Dom Adelbert Gresnigt, a Benedictine monk-artist from Maredsous who stayed in China from 1927 to 1932 and developed an indigenised architectural style. Known as the "Sino-Christian style". It was the antithesis of the style of the abbey of Maredsous and the Belgian Gothic Revival exported to China by Father De Moerloose.

The present pdf is not a scan of the printed article, which can be downloaded on https://doi.org/10.1484/J.RB.5.124394

The present pdf presents the final text of the article but its layout differs from that of the Revue Bénédictine: the pages have a larger size, which allowed to integrated the figures into the text, and the colour photos are in colour. 
Revue Bénédictine, 131 (1), June 2021, p. 264-299

[264]

\title{
UNEXPECTED CONNECTIONS
}

\section{The Benedictine AbBey OF MAREDSOUS AND Christian ARChiteCtURE IN China, 1900-1930S}

\author{
Thomas Coomans *
}

When we think about Belgian Catholic missions to China, it is not the abbey of Maredsous that first comes to mind but the Scheut Fathers in Inner Mongolia, the Flemish Friars Minor in Hubei and the Benedictine abbey of Saint-André, Bruges, as well as three great figures: the Jesuit Ferdinand Verbiest, the Lazarist Vincent Lebbe and the Benedictine Pierre-Célestin Lou. Recent research has revealed, however, that the abbey of Maredsous exerted significant but conflicting influences on missionary architecture in China from the 1900s to the 1930s through two different channels. These influences were by no means the result of a strategy pursued by the abbey of Maredsous, which, to a large extent, remained unaware of them. ${ }^{1}$

The first part of this article introduces the interwoven missionary networks that will allow us to contextualise the architectural connections of Maredsous. To which Belgian missionary congregations did the Sacred Congregation for the Propagation of the Faith (henceforth Propaganda Fide) entrust mission fields in China? How did the Benedictines contribute to the China mission? Why did the Benedictine Congregation of the Annunciation, in particular the abbey of Saint-André, Bruges, develop a China mission in the 1920s and 1930s? The second part focuses on the role of the Scheut Father Alphonse De Moerloose, an architect trained at the St Luke Art School in Ghent, who exported the Gothic Revival style of Augustus Pugin and Baron Bethune to northern China. What design method did Father De Moerloose [265] use and why was the abbey church of Maredsous one of the preferred architectural references for his major projects in China? The third section returns to the figure of Dom Adelbert Gresnigt and his architectural work; a monk-artist from Maredsous, Gresnigt spent most of his monastic life on Benedictine construction sites around the world, notably in China from 1927 to 1932. Research into Dom Gresnigt's work in China has progressed

* Prof. Thomas Coomans, KU Leuven, Department of Architecture, thomas.coomans@ kuleuven.be Personal webpage: https://www.kuleuven.be/wieiswie/en/person/00016480

1 Dom Daniel Misonne (1925-2018), who actively contributed to developing the evangelic apostolate of Maredsous in Africa, was fascinated to discover that architectural connections had also existed between Maredsous and China. He encouraged my research on Dom Gresnigt, facilitated my stays in Maredsous and followed my fieldwork in China with interest. With deep gratitude, I dedicate this article to this great scholar of monastic history and friend. 
significantly since our articles in 2013-14, ${ }^{2}$ and has also been echoed in China. ${ }^{3}$ Here, the central questions are less the works of Father Gresnigt than his networks, and why he came to develop an indigenised architectural style, known as "Sino-Christian style", which was the antithesis of the style of the abbey of Maredsous and the Belgian Gothic Revival exported to China by Father De Moerloose.

\section{INTERWOVEN NETWORKS: Belgian And Benedictine Missions on the Chinese Mainland}

Paradoxically, the success of the national and colonial Catholic mission to the Congo Free State (1885-1908) and Belgian Congo (1908-60) has long obscured the other Belgian mission fields in Latin America, India, the Philippines, China and elsewhere. ${ }^{4}$ These missions, however, were often older and less directly associated with the Belgian colonial project. Since China was never a colony and attracted missionaries from the thirteenth century onwards, the history of Christian missions to China is very complex and varied given [266] the way in which the Empire would alternately open and close to foreigners. "Belgians" played a part in the thirteenth-century Franciscan mission and the seventeenth-century Jesuit mission. Two of them have gone down in history: the Franciscan William of Rubrouck (dates unknown), who travelled to Mongolia in $1253-55,{ }^{6}$ and the Jesuit

2 Thomas CoOmans, "La création d'un style architectural sino-chrétien. L'œuvre d'Adelbert Gresnigt, moineartiste bénédictin en Chine (1927-1932)", Revue Bénédictine, 123, 2013, p. 128-170 https://doi.org/10.1484/J.RB.1.103325 ; Thomas CoOMANS, "Dom Adelbert Gresnigt, agent van de Roomse inculturatiepolitiek in China (1927-1932)", Bulletin KNOB - Koninklijke Nederlandse Oudheidkundige Bond, 113/2, 2014, p. 74-91. https://doi.org/10.7480/knob.113.2014.2.658

3 In the recent five-volume synthesis on Modern architecture in China: DONG Li 董黎, XU Haohao 徐好好 and LuO Wei 罗薇, “Xifang jiaohui shili de zai hua kuozhang ma jiaohui jianzhu de fa zhan” 西方教会势力的在 华扩张马教会建筑的发展 [Spread and church architectural developments of Western Christians in China], in: LAI Delin 赖德霖, WU Jiang 伍江 and XU Subin 徐苏斌 (eds), Zhongguo jindai jianzhu shi 中国近代建 筑史 [History of Modern Architecture of China], vol. 1, Beijing: China Architecture and Building Press, 2016, p. 317-402 (especially p. 337-343 and 400-402 on Sino-Christian style and Dom Gresnigt, and p. 394-400 on Father De Moerloose).

4 About Belgian missionaries in India: Luc VINTS, "Vier moet branden. Belgische missionarissen in India", in: Idesbald GODDEERIS (ed.), Het wiel van Ashoka. Belgisch-Indiase contacten in historisch perspectief, Leuven: Leuven University Press, 2013, p. 83-102.

5 See: Nicolas StandaERT (ed.), Handbook of Christianity in China. Volume One: 635-1800, Leiden-Boston: Brill, 2011; R. Gary TIEDEMANN (ed.), Handbook of Christianity in China. Volume Two: 1800-present, LeidenBoston: Brill, 2010.

6 Peter JACKSON and David Morgan, The Missions of Friar William de Rubruck: His Journey to the Court of the Great Khan Möngke, 1253-1255, London: Hakluyt Society, 1990. Rubrouck village is located in French Flanders (département du Nord), but was part of the County of Flanders in the thirteenth century. 
Ferdinand Verbiest (1623-88), who lived in Beijing from 1659 to 1688 and was the astronomer to Emperor Kangxi. ${ }^{7}$

From 1858-60, Catholic missionaries were allowed to circulate freely throughout China and the Propaganda Fide began organising the mission by assigning vicariates apostolic. Three French congregations carved up the lion's share - the Congregation of the Mission (Lazarists or Vincentians) took the north (Beijing, Tianjin, Hebei), Mongolia, Zhejiang and Jiangxi; the Jesuits received Shanghai, Jiangsu and Anhui; the Foreign Missions of Paris held the south (Guangdong, Guangxi), the southwest (Sichuan, Yunnan, Guizhou) and the northeast (Manchuria), while Italian Franciscans were entrusted with the centre (Shaanxi, Shanxi, Hubei, Hunan), German Franciscans with Shandong, and Spanish Dominicans with Fujian. ${ }^{8}$ Every time it became clear that an ecclesiastical circumscription was too vast, the Propaganda Fide reconfigured the map of vicariates apostolic by calling upon other congregations according to the geopolitical interests of both the Church and Western nations, resulting in a "feudal landscape" of colonisation by national missionary congregations. ${ }^{9}$ From 1864, the Belgian Scheut Fathers replaced [267] the Lazarists in the extensive territories north of the great wall and would develop no fewer than five vicariates apostolic there. ${ }^{10}$ The Flemish Franciscans relieved Italian Franciscans in western Hubei from 1870 and ran the vicariate apostolic of Ichang. ${ }^{11}$ (see Table 1) This took place before the colonisation of Congo that would massively redirect Belgian missionary vocations to Belgian Congo, from the late 1890s, and Ruanda-Urundi, from 1922, to the detriment of other mission fields.

In the aftermath of the First World War, the need to change the China Catholic Mission became urgent in what was now the Republic of China (1912). Not only was the number of Chinese Christians and the Protestant educational penetration of China growing, but Chinese Nationalism (KMT founded in 1919) and Communism (CCP founded in 1921) had a profound effect on society. With the apostolic letter Maximum illud published by Pope Benedict XV on 30 November 1919, ${ }^{12}$ the Holy

7 See, among numerous publications on Father Verbiest (1623-88), the recent book: Noël GolvERS, Postulata vice-provinciae sinensis in urbe proponenda. A Blueprint for a Renewed SJ Mission in China (Leuven Chinese Studies, 40), Leuven: Ferdinand Verbiest Institute, 2018.

8 R. Gary Tiedemann, Reference Guide to Christian Missionary Societies in China from the Sixteenth to the Twentieth Century, Armonk-London: Sharpe, 2009 p. 3-45.

9 Thomas Coomans, "Islands on the Mainland: Catholic Missions and Spatial Strategies in China, 1840s-1940s", in: Bram CleYs, Bruno De MeULDER, Jan DE MAEYER and Allen M. HowARD (eds), Missionary Places, 18501950. Imagining, Building, Contesting Christianities (KADOC Artes, 17), Leuven: Leuven University Press, 2021 (forthcoming).

10 Daniël Verhelst and Nestor PyCKe (eds), C.I.C.M. Missionaries, Past and Present 1862-1987. History of the Congregation of the Immaculate Heart of Mary (Scheut / Missionhurst) (Verbistiana 4), Leuven: Leuven University Press, 1995, p. 40-65, 88-116, 158-189, 256- 281.

11 Carine DuJARdin, Missionering en Moderniteit. De Belgische minderbroeders in China 1872-1940 (KadocStudies 19), Leuven: Leuven University Press, 1996.

12 Pope BENEDICT XV, Apostolic letter Maximum Illud on the propagation of the faith throughout the world, 30 November 1919. http://www.vatican.va/content/benedict-xv/en/apost letters/documents/hf_benXV_apl_19191130_maximum-illud.html [accessed 20 July 2020]. 
See launched its policy of "inculturation", which was particularly aimed at putting an end to the French Protectorate and the colonial-style mission to China. ${ }^{13}$ The Belgian Vincent Lebbe 雷鳴遠 (1877-1940), who entered the Congregation of the Mission in 1895 and arrived in Beijing in 1901, fought his whole life for the shift from a Eurocentric Catholic mission under French Protectorate to an established Chinese Church with Chinese bishops and clergy ${ }^{14}$ His action was decisive in China, as well as in Rome and Belgium where he coordinated the work of Chinese students from 1920 to 1927. In 1922, Monsignor Celso Costantini 剛恆毅 (1876-1958) was sent to China as Apostolic Delegate with the mission to implement the new missionary policy and stimulate new waves of Catholic missionaries [268] from the USA, Canada, Ireland, Italy, Spain, The Netherlands, Hungary, Poland, Austria and Switzerland. Belgian Benedictines from the abbey of Saint-André were involved in several projects in Beijing and Sichuan that were in keeping with the spirit of Maximum illud, as will be developed further. Finally, the Society of Auxiliaries of the Mission (SAM), founded in Brussels in 1926 by Father Lebbe and Father André Bolland (1891-1955) to offer assistance in the apostolic vicariates administered by Chinese bishops and clergy, sent its first priests to China in $1930 .{ }^{15}$ (see Table 1)

The contribution of female Belgian missionaries to the Chinese mission was different, but no less important. Usually the vicars apostolic urged Western women's missionary institutes to undertake ad hoc diocesan projects in the fields of health and education. Consequently, Belgian sisters from the Missionary Canonesses of St Augustine were sent to the vicariates apostolic held by the Scheut Fathers, ${ }^{16}$ and Franciscan Missionaries of Mary to the vicariates apostolic of Ichang, held by Belgian Franciscans, as well as to some sites operated by Belgian Scheut Fathers. ${ }^{17}$ Two late and unsuccessful attempts must also be mentioned: one by the Saint-Michel's Carmel Bruges, in Guangzhou in 1931, ${ }^{18}$

13 Claude Soetens, L'Église catholique en Chine au XXe siècle (L'histoire dans l'actualité, 6), Paris: Beauchesne, 1997, p 29-56.

14 Arnaud Join-Lambert, Paul Servais, Chung Heng SHEN and Eric DE PAYEN (eds), Vincent Lebbe et son héritage, Louvain-la-Neuve: UCL Presses universitaires de Louvain, 2017; Jacques LECLERCQ, Thunder in the Distance. The Life of Père Lebbe, New York: Sheed \& Ward, 1958.

15 See the journal: SAM. Societas Auxiliarum Missionum, Brussels: Société des Auxiliaires des Missions, 193462.

Onze Missiën. Kanunnikessen-missionarissen van den H. Augustinus / Het Missieveld der kanunnikessenmissionarissen van Sint-Augustinus "De Jacht” Heverlee-Leuven, 1928-62.

17 This international congregation had several houses in Belgium, including a central house in Woluwe-SaintPierre (Brussels) and an international novitiate in Gooreind (Wuustwezel), as well as 45 houses in China in 1933 (see Table 2). In 1900, the Boxers killed seven sisters in Taiyuan (Shanxi), including the Belgian sister Amandina of Schakkebroek [Maria-Pauline Jeuris] (1872-1900), who was canonised in 2000. Almanak van de Franciscanessen Missionarissen van Maria, Brussels, 1-26, 1906-40.

18 Matteo Nicolini-ZANi, Christian Monks on Chinese Soil. A History of Monastic Missions to China, Collegeville, MA: Liturgical Press, 2016, p. 92-95. This book is an English translation of: Matteo NICOLINI-ZANI, Monaci cristiani in terra cinese. Storia della missione monastica in Cina, Magnano: Edizioni Qiqajon, Comunità di Bose, 2014. 
TABLE 1 - Belgian foundations and numbers of Belgian missionaries in China [270]

\begin{tabular}{|c|c|c|}
\hline DATES & MISSIONARY CONGREGATION & MISSION FIELD IN CHINA \\
\hline \multicolumn{3}{|c|}{ MEN } \\
\hline 1864-1956 & $\begin{array}{l}\text { Congregation of the Immaculate } \\
\text { Heart of Mary (CICM) 聖母聖心 } \\
\text { 會, "Scheut Fathers", mother } \\
\text { house in Scheut (Anderlecht) } \\
\text { - } 570 \text { Belgian fathers and brothers }\end{array}$ & $\begin{array}{l}\text { Vicariates apostolic of Xiwanzi 西湾子 I } \\
\text { Chongli 崇礼 (Hebei), Suiyuan 綏遠(Inner } \\
\text { Mongolia), Datong 大同 (Shanxi), Jehol 热 } \\
\text { 河 / Jinzhou 锦州 (Liaoning), Yinchuan 银 } \\
\text { 川 (Ningsia); houses in Beijing 北京, } \\
\text { Tianjin 天津, Shanghai 上海 [move to } \\
\text { Hong Kong 香港, } 1951 \text { and Taiwan 臺灣, } \\
\text { 1956] }\end{array}$ \\
\hline $1870-1953$ & $\begin{array}{l}\text { Order of the Friars Minor (OFM) 聖 } \\
\text { 方濟各會 } \\
-93 \text { Belgian fathers and } 6 \text { brothers } \\
\text { from the Flemish Province of St } \\
\text { Joseph }\end{array}$ & $\begin{array}{l}\text { Vicariate apostolic of Ichang 宜昌 (Hubei) } \\
\text { [move to Hong Kong 香港 and Taiwan 臺 } \\
\text { 灣 from 1951] }\end{array}$ \\
\hline 1927-1952 & $\begin{array}{l}\text { Benedictine Congregation of the } \\
\text { Annunciation (OSB) 本篤會 } \\
-9 \text { Belgian monks from the abbey } \\
\text { of Saint-André }\end{array}$ & $\begin{array}{l}\text { Monasteries at Xishan 西山 (Sichuan), } \\
1929-49 \text { and Chengdu 1949-52 [move to } \\
\text { California in 1952] }\end{array}$ \\
\hline 1930-1955 & $\begin{array}{l}\text { Society of Auxiliaries of the } \\
\text { Mission (SAM) 服務會 } \\
\text { - } 25 \text { Belgian priests sent to China }\end{array}$ & $\begin{array}{l}\text { Active in Beijing 北京, Anguo 安國 } \\
\text { (Hebei), Xuanhua 宣化 (Hebei), Haimen } \\
\text { 海門 (Jiangsu) [move to Taiwan 臺灣 in } \\
\text { 1952] }\end{array}$ \\
\hline \multicolumn{3}{|c|}{ WOMEN } \\
\hline 1889-195? & $\begin{array}{l}\text { Franciscan Missionaries of Mary } \\
\text { (FMM) 瑪利亞方濟各傳教修 } \\
\text { 會 Franciscaines Missionnaires } \\
\text { de Marie, French-international } \\
\text { congregation with several houses } \\
\text { in Belgium (Woluwe, Antwerp, } \\
\text { Mechelen, Wuustwezel) - in 1936: } \\
\text { about } 50 \text { Belgian sisters in China } \\
\end{array}$ & $\begin{array}{l}\text { Work in dispensaries, orphanages and } \\
\text { schools: from } 1889 \text { with Belgian } \\
\text { Franciscans in Yichang 宜昌 (Hubei); } \\
\text { from } 1898 \text { with Scheut Fathers in Xiwanzi } \\
\text { 西灣子 (Hebei), Jining 集寧 (Inner } \\
\text { Mongolia), Datong 大同 (Shanxi) [move } \\
\text { to other mission fields] }\end{array}$ \\
\hline 1923-195? & $\begin{array}{l}\text { Missionary Canonesses of St } \\
\text { Augustine (MCSA) 聖母聖心傳 } \\
\text { 教女修會 Zusters Missionarissen } \\
\text { van het Onbevlekt Hart van Maria } \\
\text { / Zusters van de Jacht (ICM), } \\
\text { Heverlee, Leuven - in 1936: about } \\
30 \text { Belgian sisters in China (12 in } \\
\text { the General Hospital of Suiyuan } \\
\text { 綏遠) }\end{array}$ & $\begin{array}{l}\text { Work with Scheut Fathers from 1923; } \\
\text { dispensaries, orphanages and schools in } \\
\text { the vicariates apostolic of Yinchuan 銀川, } \\
\text { Suiyuan 綏遠 (Inner Mongolia), Xiwanzi } \\
\text { 西灣子 (Hebei) [move to Junk Bay 將軍 } \\
\text { 澳, Hong Kong 香港, in 1954, and found } \\
\text { a house in Taipei 臺北 in 1960] }\end{array}$ \\
\hline $1931-1937$ & $\begin{array}{l}\text { Discalced Carmelite Nuns (OCD) } \\
\text { 聖母聖衣隱修會 - } 7 \text { Belgian } \\
\text { nuns from the Carmel of Saint- } \\
\text { Michel, Bruges }\end{array}$ & $\begin{array}{l}\text { Carmel in Guangzhou 广州 (Guangdong) } \\
\text { [move to Hong Kong 香港 in } 1937 \text { and } \\
\text { Macao 澳門 in 1941] }\end{array}$ \\
\hline 1947-1949 & $\begin{array}{l}\text { Lay Auxiliaries of the Mission } \\
\text { (ALM) 雷鳴遠國際女子服務 } \\
\text { 團 Auxiliaires laïques des } \\
\text { missions - } 7 \text { Belgian lay women }\end{array}$ & $\begin{array}{l}\text { Communities in Nanjing 南京 (Jiangsu) } \\
\text { and Beijing 北京 [move to Hong Kong 香 } \\
\text { 港 in } 1949 \text { and Taiwan 臺灣 in 1953] }\end{array}$ \\
\hline
\end{tabular}


the other by the Lay Auxiliaries of the Mission in $1947 .{ }^{19}$ (see Table 1) Twelve years of wars - Second Sino-Japanese [269] War (1937-45) followed by the Chinese Civil War (1945-49) - deeply affected society and eventually led to the expulsion of all missionaries from China in the early years of the People's Republic of China. Other Belgian men and women who felt called by the China mission entered foreign congregations, mainly French ones, ${ }^{20}$ such as Vincent Lebbe at the Congregation of the Mission or sisters at the Daughters of Charity. ${ }^{21}$ This phenomenon has not been studied as such and therefore cannot be quantified, except in the case of the Jesuits. ${ }^{22}$

The Benedictines' contribution to the China mission has been studied by Father Matteo NicoliniZani in his excellent book on the history of monastic missions to China. ${ }^{23}$ Their projects came late, were very different from each other, were supported by Benedictine congregations from the USA, Belgium and Germany, and involved Benedictine monks from the USA, Germany, Belgium, France, Italy and The Netherlands, as well as nuns from the USA and Switzerland (see Table 2). First, in 1909, the Missionary Benedictines of St Ottilien started a mission in Korea and, from 1920, ran the vicariate apostolic of Wonsan that covered the northern part of Korea and territories in northeast China with important Korean minorities. Dom Boniface Sauer (1877-1950), as vicar apostolic of Wonsan, became the first Benedictine with episcopal jurisdiction over a portion of Chinese territory. This part of China became the prefecture apostolic of Yanji in 1928 and vicariate apostolic in 1937 1937 - "the very best but also the very poorest mission to China" -, with Dom Theodor Breher (18891950) as vicar apostolic. The monks combined [271] pastoral and monastic life in the abbey of the Holy Cross in Yanji. ${ }^{24}$ Olivetan Benedictine Sisters of the Holy Cross also founded a monastery in

19 Margaret G. BLASER, The Lay Auxiliaries of the Missions, master's thesis, Loyola University Chicago, 1952, https://ecommons.luc.edu/cgi/viewcontent.cgi?article=1912\&context=luc theses [accessed on Loyola eCommons, 2 September 2020]; Raymonde MARTINEAU, "Des laïques sur les traces du père Lebbe", in: Arnaud JoIn-Lambert, Paul Servais, Chung Heng Shen and Eric DE PAYEN (eds), Vincent Lebbe et son héritage, Louvain-la-Neuve: UCL Presses universitaires de Louvain, 2017, p. 169-174.

20 These include Georges-Marie de Jonghe d'Ardoye (1887-1961), who joined the French Mission of Paris and was sent to China in 1910. He became secretary of the Synodal Commission in Beijing, vicar apostolic of Yünnanfu (Kunming, 1933-38) and had a career as a high-ranking Vatican diplomat.

21 Belgian nuns appear on the lists of martyrs in China. For example, two of the ten "French nuns" (Sisters of Charity) who were raped and killed during the Tianjin Massacre on 21 June 1870 were Belgian (Sr. Marquet, the superior of the community, and Sr. Adam). See: Fleur ChabAILle-WANG, "Une mémoire ambiguë en Chine: le 'Massacre de Tianjin' en 1870", Newsletter Asialyst, 26 October 2017, https://asialyst.com/fr/2017/10/26/chine-memoire-ambigue-massacre-tianjin-1870/ [accessed 9 Sept. 2020].

22 A total of 1,570 Jesuits of 26 nationalities went to China from 1842 to 1949. Fourteen Belgians joined French Jesuit provinces and were sent: 7 to Jiangnan (Shanghai, Jiangsu, Anhui), 1 to Xuzhou (Jiangsu), 5 to XianXian (Hebei) and 1 to Macao. See: Olivier LARDINOIS, Fernando MATEOS and Edmund RYDEN, Directory of the Jesuits in China from 1842 to 1955, Taipei: Taipei Ricci Institute, 2018, p. 233-280.

M. NiCOLINI-ZANI, Christian Monks on Chinese Soil... (see n. 18), p. 170-259.

24 Johannes MAHR, Aufgehobene Häuser. Missionsbenediktiner in Ostasien. Teilband 2: Die Abteien Tokwon und Yenki (Ottilianer Reihe, 9), Sankt-Ottilien: EOS Verlag, 2009, p. 349-720; M. NICOLINI-ZANI, Christian Monks on Chinese Soil... (see n. 18), p. 243-250. 


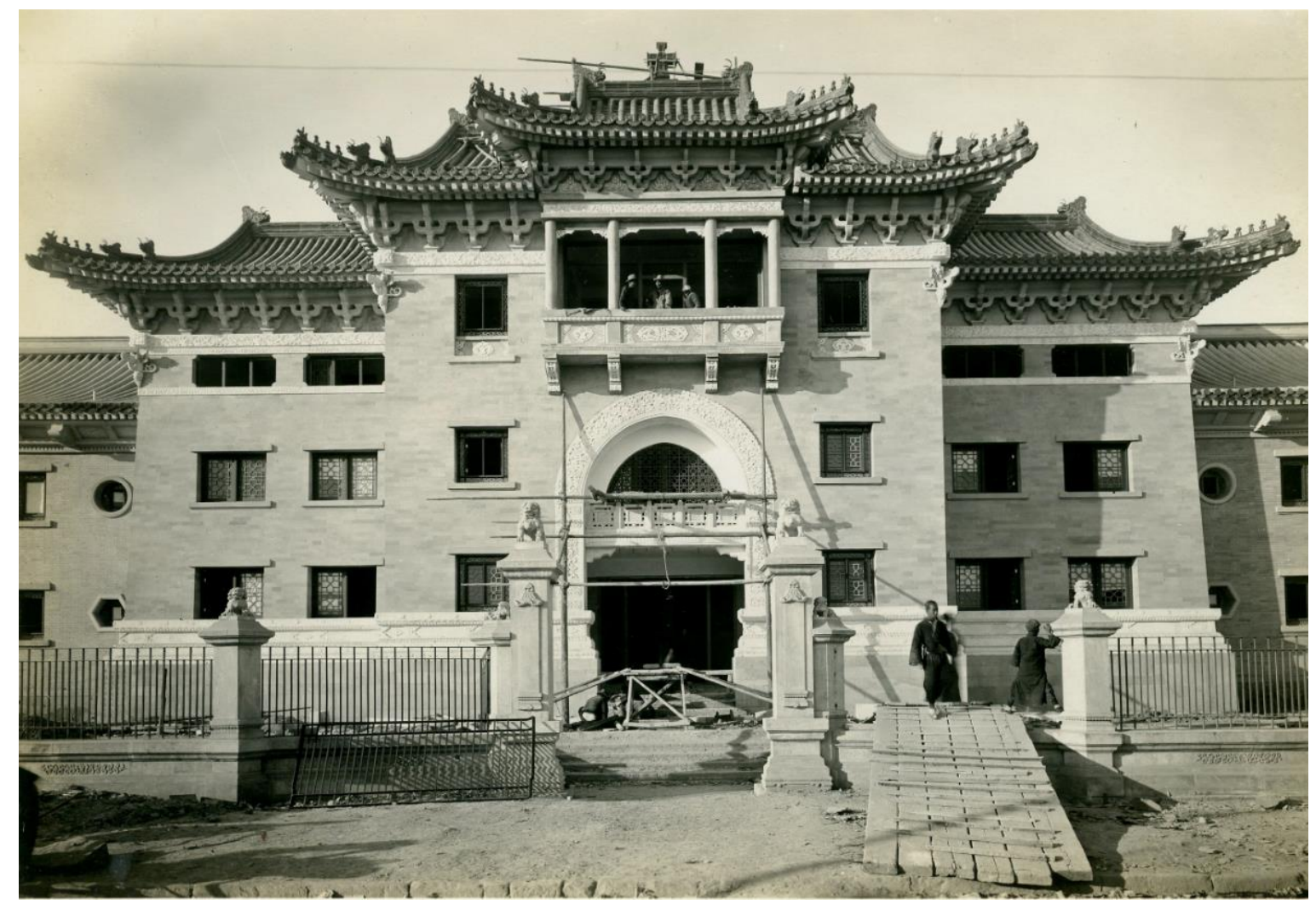

Fig. 1. Beijing, Fu Jen Catholic University of Peking, main entrance, A. Gresnigt, 1930 (Archives of the Abbey of Maredsous).

Yanji and developed a health and educational apostolate. The mission was in a particularly sensitive area subject to Japanese invasion in 1932, the puppet Empire of Manchukuo from 1934, a Soviet Russian takeover in 1945 and eventually Chinese Communists from 1947, which quickly ended the mission of Yanji.

The second Benedictine mission to China was prestigious and had the foundation of the Catholic University of Peking, also named Fujen University, as its goal. From the outset, however, the American-Cassinese Congregation and St Vincent Archabbey, Latrobe, were far from enthusiastic, but could not refuse such a request from the Holy See. From 1924 to 1933, a community involving American and European monks, including one from Maredsous, tried to combine academic teaching and monastic life under Prior Ildephonse Brandstetter (1870-1945). ${ }^{25}$ Opening its doors in 1925, the university achieved remarkable results in a short time, reaching more than one thousand students in 1932 and erecting in the heart of Beijing a remarkable university building in Sino-Christian style [Fig. 1], designed by Dom Adelbert Gresnigt - as will be developed in the third part of this article. ${ }^{26}$

M. NiCOLINI-ZANi, Christian Monks on Chinese Soil... (see n. 18), p. 171-190.

Bulletin of the Catholic University of Peking, 8 issues, 1926-31; Hubert VANDERHOVEN, "L'Université Catholique Chinoise de Pékin", Le Bulletin des Missions, 8, 1926, p. 174-179; Hubert VANDERHOVEN, "L’Université catholique de Péking", Le Bulletin des Missions, 8/7, 1927, p. 208-212. 
Six American nuns from St Benedict's Monastery, St Joseph, were sent to Beijing in 1930 with the intention of founding the Women's College of the Catholic University of Peking. The combination of the difficulty in observing monastic life, the excessive costs of the university, the global economic crisis that began in 1929, and the unexpected death of Dom Arelius Stehle (1877-1930) - the archabbot of St Vincent and chancellor of the university-, precipitated the American abbeys' decision to withdraw. The Holy See was unhappy and replaced the Benedictines with German missionaries from the Society of the Divine Word in $1933 .{ }^{27}$ Some monks remained in China and founded a small [272] monastery in Kaifeng after having been canonically transferred from the community of St Vincent to that of St Procopius Abbey, Lisle in 1936. The Italian Franciscan bishop of Kaifeng also welcomed the five remaining nuns from Beijing. However, the war years 1937-49 were hardly conducive to new developments; after many vicissitudes, the last members of these small religious communities were expelled from China.

The third Benedictine project in China concerned the abbey of Saint-André, Bruges. The abbey was involved in missions in Brazil and Congo, but had developed an interest in China since 1913 thanks to a friendly relationship with Father Vincent Lebbe - whose brother Dom Beda Lebbe (18791948) was a monk at Maredsous - and his work on behalf of the Chinese students in Belgium. Vincent Lebbe became a friend of Dom Théodore Nève (1879-1963), the abbot of Saint-André, and broadened the scope of the community to China. ${ }^{28}$ In 1924, he wrote several articles in the Bulletin des Missions, a magazine published by the abbey of Saint-André. Two years later, when Pope Pius XI called for more contemplative engagement in the missions in his encyclical letter Rerum Ecclesiae and mentioned the Trappist abbey of Yangjiaping in the vicariate apostolic of Beijing, ${ }^{29}$ Dom Nève felt that the appeal of China was gaining momentum and involved his abbey in the project of Dom Jean Joliet (1870-1937), a monk from the abbey of Solesmes who wanted to inculturate Benedictine contemplative monastic life in China. ${ }^{30}$ Dom Joliet and a monk from Saint-André, Dom Pie de Cocquéau, ${ }^{31}$ were sent to Beijing in 1927 and spent a year with the American Benedictines before exploring Sichuan, south-west China. Land was bought near Shunqing 顺庆 (Nanchong 南充) at a

27 John Shujie CHEN, The Rise and Fall of Fu Ren University Beijing: Catholic Higher Education in China, New York: Routledge Falmer, 2004.

28 Christian Papeians de Morchoven, "The China Mission of the Benedictine Abbey of Sint-Andries (Bruges)", in Jeroom HeYNDRICKX (ed.), Historiography of the Chinese Catholic Church. Nineteenth and Twentieth Centuries (Louvain Chinese Studies, 1), Leuven: Ferdinand Verbiest Foundation, 1994, p. 305-310.

29 Pope PIUS XI, Rerum Ecclesiae. Encyclical letter on Catholic missions, 28 February 1926, § 28. http://www.vatican.va/content/pius-xi/en/encyclicals/documents/hf_p-xi_enc_28021926_rerumecclesiae.html Patrick TAVEIRNE 譚永亮, “Re-reading the Apostolic Letter Maximum Illud”, in: Weiying KU 古伟瀛 and Xiaoyang ZHAO 赵晓阳 (eds), Jidu zongjiao yu jindai Zhongguo 基督宗教与近代中国 [Multiaspect Studies on Christianity in modern China], Beijing: Social Sciences Academic Press, 2014, p. 64-87.

30 M. Nicolini-Zani, Christian Monks on Chinese Soil... (see n. 18), p. 190-243.

31 Dom Pie de Cocquéau des Mottes (1882-1961) was a profess from Maredsous 1908 who had been transferred to Saint-André in 1920. He taught French at the Catholic University of Peking for a year and co-founded Xishan in 1928 before soon returning to Belgium. 


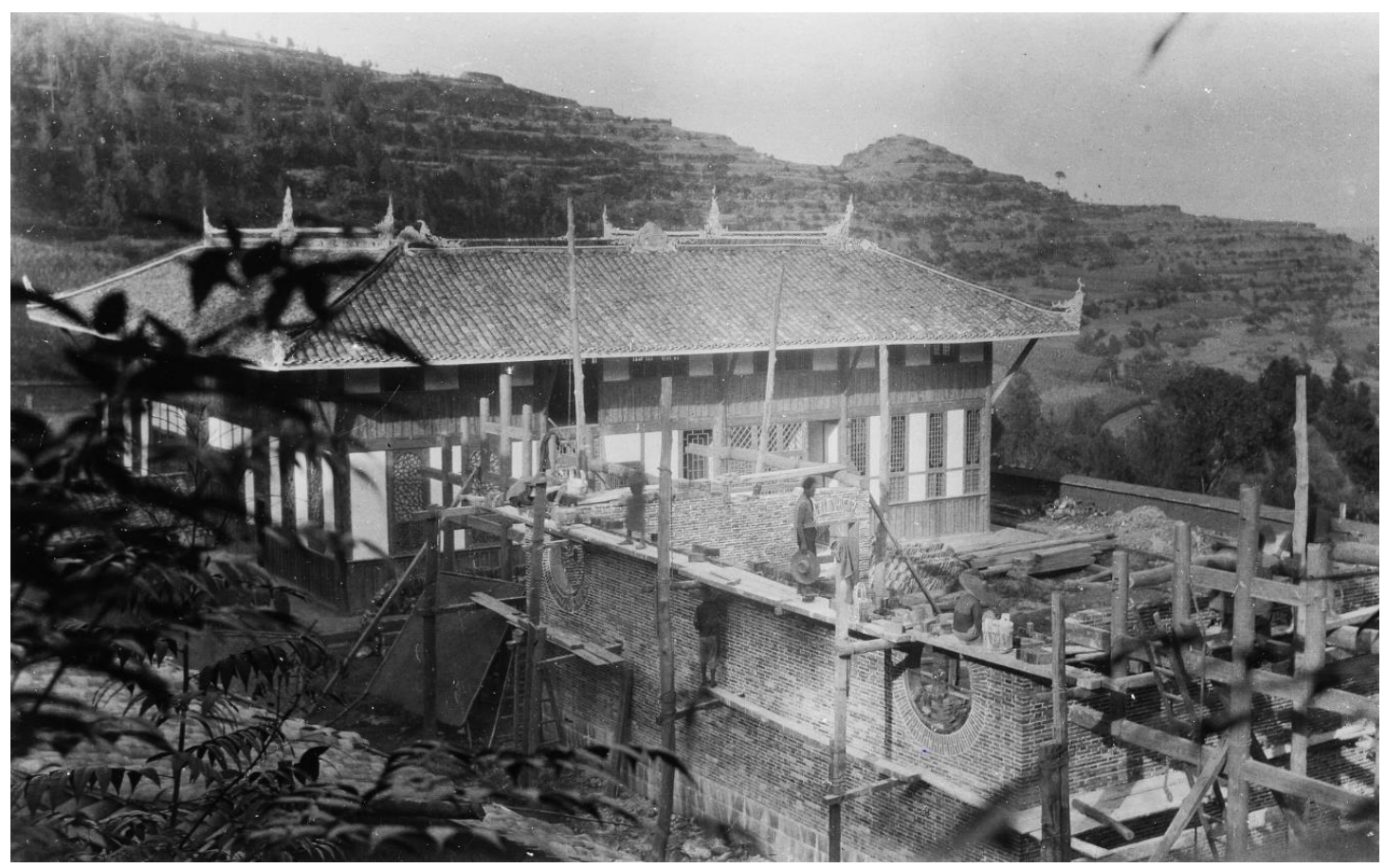

Fig. 2. Priory of Xishan under construction, ca 1929 (Archives of the Abbey of Maredsous).

place called Xishan 西山 (west mountain) and the construction of buildings in the vernacular architecture soon [273] began, using local carpenters so that "the monastery will be a Chinese House" 32 [Fig. 2]. After the arrival of two more monks, the Priory of Xishan was founded on 29 March 1929. Internal tensions about how to Sinicise monastic liturgy and educate novices led to the retirement of Dom Joliet in a nearby hermitage. At the turn of 1934-35, Dom Nève visited China and made plans for a second monastic foundation close to Nanjing. However, the war would result in the exodus of the community from Xishan to Chengdu and a new project for a university-level Chinese Western Cultural Research Institute. Important modern Chinese-style buildings including a library were erected with American funding and opened their doors in July 1949, before closing soon after. In 1952, Prior Raphaël Vinciarelli (1897-1972) and the last nine foreign monks were expelled from China and moved to the USA. At first glance, Xishan might look like a marginal experience, but its innovative attempt at the real inculturation of the Benedictine monastic tradition was widely promoted through the influential Bulletin des Missions. ${ }^{33}$

32 Matteo Nicolini-ZANI, "The Monastery Will Be a Chinese House: The Inculturation of the Church in China from the Perspective of the History of Catholic Monasticism", Religions \& Christianity in Today's China - ejournal RCTC, 7/3, 2017, p. 41-53.

33 Théodore Neve, "Le Monastère des SS. Pierre et André de Si Chan", Le Bulletin des Missions, 9/7, January 1929, p. 289-296; Théodore NEVE, "Le Prieuré des SS. Pierre et André de Si Chan", Le Courrier monastique chinois. Le Bulletin des Missions, 10, Suppl. 1, September 1930, p. 1-14; Jehan JOLIET, "Une Tâche Monastique", Ibidem, p. 15-25; Hildebrand MARGA, "Inauguration du Monastère Chinois", Ibidem, p. 26-30; Raphaël VinCIARELLI, "Dom Jehan Joliet et son œuvre monastique en Chine", Contemplation et Apostolat. 
Table 2. Benedictine Missions to China [274]

\begin{tabular}{|c|c|c|c|}
\hline DATES & $\begin{array}{c}\text { COMMUNITY IN CHINA: } \\
\text { ORIGIN, CONGREGATION } \\
\text { AND NUMBER }\end{array}$ & $\begin{array}{c}\text { LOCATION, } \\
\text { APOSTOLATE AND } \\
\text { ARCHITECTURE } \\
\end{array}$ & $\begin{array}{l}\text { AFTER CHINA } \\
\text { SUPPRESSION }\end{array}$ \\
\hline \multicolumn{4}{|c|}{ MEN } \\
\hline $1924-1933$ & $\begin{array}{l}\text { American Cassinese } \\
\text { Congregation - } \\
\text { Benedictine Congregation } \\
\text { of St Vincent, Latrobe } \\
\text { (Pennsylvania, USA) } \\
\text { - } 15 \text { monks, } 3 \text { oblates, } 1 \\
\text { deacon, } 2 \text { clerics }\end{array}$ & $\begin{array}{l}\text { Beijing 北京: Catholic } \\
\text { University of Peking / } \\
\text { Fujen University 輔仁大 } \\
\text { 學 in the Chinese mansion } \\
\text { Tao Beile Fu, 1925; } \\
\text { university building, modern } \\
\text { Chinese style, 1929-33 }\end{array}$ & $\begin{array}{l}\text { 1934: some monks go back } \\
\text { to their original abbeys: } \\
\text { others remain in Beijing 北 } \\
\text { 京 or move to Kaifeng 开封 } \\
\text { (Henan) }\end{array}$ \\
\hline $1934-195 ?$ & $\begin{array}{l}\text { American Cassinese } \\
\text { Congregation - } \\
\text { Benedictine Congregation } \\
\text { of St Procopius, Lisle } \\
\text { (Illinois, USA) } \\
-6 \text { monks: } 3 \text { from Beijing } \\
\text { and } 3 \text { from St Procopius }\end{array}$ & $\begin{array}{l}\text { Kaifeng 开封 (Henan): } \\
\text { priory; } \\
\text { Beijing 北京: house }\end{array}$ & $\begin{array}{l}\text { move to Taiwan 台灣 and } \\
\text { found the Priory of Chiayi 嘉 } \\
\text { 義 in } 1967\end{array}$ \\
\hline $1927-1952$ & $\begin{array}{l}\text { Benedictine } \\
\text { Congregation of the } \\
\text { Annunciation, abbey of } \\
\text { Saint-André / Sint- } \\
\text { Andries, Bruges (West } \\
\text { Flanders, Belgium) } \\
-13 \text { monks (9 Belgian, } \\
1 \text { Italian, } 2 \text { French and } 1 \\
\text { Chinese) }\end{array}$ & $\begin{array}{l}\text { Xishan 西山 (Sichuan): } \\
\text { priory, vernacular style, } \\
\text { 1929-49; Chengdu 成都 } \\
\text { (Sichuan): priory and } \\
\text { Chinese Western } \\
\text { Cultural Research } \\
\text { Institute, modern } \\
\text { Chinese style, 1949-50 }\end{array}$ & $\begin{array}{l}\text { move to the USA in } 1952 \\
\text { and found the Priory of } \\
\text { Valyermo (California) in } \\
\text { 1995, abbey in } 1992\end{array}$ \\
\hline $1928-1952$ & $\begin{array}{l}\text { Missionary Benedictine } \\
\text { Congregation of St } \\
\text { Ottilien (Bavaria, } \\
\text { Germany) } \\
\text { - about } 20 \text { German and } \\
\text { Korean }\end{array}$ & $\begin{array}{l}\text { Yanij 延吉 (Jilin): } \\
\text { prefecture apostolic, 1928; } \\
\text { vicariate apostolic from } \\
1937 \text { - Holy Cross Abbey, } \\
\text { 1933-45, and church, 1937 } \\
\text { - Dunhua 돈화시 / 敦化, } \\
\text { modern church by Alwin } \\
\text { Schmid OSB, 1940-42 } \\
\end{array}$ & $\begin{array}{l}\text { 1949-52: move to South } \\
\text { Korea (Waegwan Abbey 성 } \\
\text { 베네딕도회 왜관수도원) }\end{array}$ \\
\hline \multicolumn{4}{|c|}{ WOMEN } \\
\hline $1930-1949$ & $\begin{array}{l}\text { Benedictine Sisters, from } \\
\text { St Benedict Abbey, St } \\
\text { Joseph (Minnesota, USA) } \\
-6 \text { nuns in Beijing, } 10 \text { in } \\
\text { Kaifeng }\end{array}$ & $\begin{array}{l}\text { Beijing 北京: girls } \\
\text { secondary school, } \\
\text { modern Chinese style, } \\
\text { 1932-35; Kaifeng 开封 } \\
\text { (Henan), modern } \\
\text { Chinese style, from } 1935\end{array}$ & $\begin{array}{l}\text { some return to the USA, } \\
\text { others move to Tokyo and } \\
\text { Taiwan (Priory of Danshui } \\
\text { 淡水) }\end{array}$ \\
\hline $1931-1946$ & $\begin{array}{l}\text { Olivetan Benedictine } \\
\text { Sisters of the Holy Cross, } \\
\text { Kloster Heiligkreuz, Cham } \\
\text { (Switzerland) - } 21 \text { Western } \\
\text { nuns and ? Korean }\end{array}$ & $\begin{array}{l}\text { Yanji 延吉 (Jilin): } \\
\text { monastery and } \\
\text { dispensaries and schools } \\
\text { in mission stations }\end{array}$ & $\begin{array}{l}\text { 1946: Western nuns back } \\
\text { to Cham; Korean nuns to } \\
\text { Korea (Priory of Busan } \\
\text { 부산시) }\end{array}$ \\
\hline
\end{tabular}

Supplément au Bulletin des Missions, 17/1, June 1938, p. 6-11; Wan Sang MA, "Le Monastère de Si shan en Chine", Le Bulletin des Missions. Le Courrier de l'apostolat monastique, 13, Suppl. 1, August 1934, p.4-14. 
The most famous Chinese Benedictine monk was Lu Zhenxiang / Lou Tseng-Tsiang 陸徵祥 (1871-1949), who entered Saint-André in 1927 after having first considered joining Maredsous as an oblate. ${ }^{34}$ We will neither go into the details of the exceptional life of this high-ranking diplomat and politician, nor into the circumstances of his Catholic and monastic vocation, but will focus on his art of connecting ideas and people. ${ }^{35}$ Dom Pierre-Célestin Lou became an exemplary [275] monk, learned Latin and theology, was ordained priest in 1935 by Mgr Celso Costantini, made titular Abbot of St Peter's Abbey in Ghent by Pope Pius XII in 1946, and passed away on 15 January 1949 before having fulfilled his dream to return to China and found an abbey. From his monastic family of SaintAndré, Dom Lou continued to serve peace in China and the world as a Catholic and Confucianist. He was acquainted with most of the people and places mentioned in this article and was in epistolary contact with world leaders, members of the Catholic hierarchy, missionaries to China, Chinese students in Belgium etc., received visits and monitored the evolution of Chinese society before and during wartime. Last but not least, Dom Lou introduced Zhang Chongren 張充仁 / Tchang (190798) to Georges Rémi / Hergé (1907-83) in 1932; together they created The Blue Lotus, a comic about interracial friendship and Tintin's best adventure. ${ }^{36}$

\section{Belgian Gothic IN CHINA: St Luke, Father Alphonse De Moerloose and Maredsous}

The 1860s were a pivotal moment in the history of the Catholic Revival in Belgium. The Church hierarchy was challenged by industrialisation, Liberalism and a general loss of moral values that impacted society, consequently choosing to hold Catholic congresses at Malines $(1863,1864,1867)$ to define a new strategy. The field of the arts and architecture were consolidated around the Catholic artist Jean-Baptiste Bethune (1821-94) and the St Luke schools that aimed at educating artists \& craftsmen as agents of a Catholic crusade in modern liberal society. ${ }^{37}$ The first St Luke School began modestly in Ghent in 1863-64 from the encounter of three Ultramontanes: Jean-Baptiste Bethune, the artist-ideologist and guarantor of the Gothic Revival orthodoxy inherited from Augustus W.M. Pugin [276] (1812-52), Joseph de Hemptinne (1822-1909), a Catholic tycoon and sponsor of the

34 C. Papeians de Morchoven, "The China Mission...” (see n. 28), p. 308.

35 See his autobiography: Pierre-Célestin Lou Tseng-Tsiang, Ways of Confucius and of Christ, London: Burns Oates, 1948. Dom Lou had been an ephemeral Prime Minister of the Republic of China in 1912, Minister of Foreign Affairs in several cabinets from 1916 to 1920, head of the Chinese delegation at the Paris Peace Conference in 1919 and ambassador of China to the League of Nations in Geneva from 1922 to 1927.

36 The story was serialised weekly from August 1934 to October 1935. Lu Zhenxiang knew Ma Xiangbo 馬相伯 (1840-1939), famous educator and great-uncle of Tchang, as well as Father Léon Gosset, collaborator of Father Lebbe as chaplain of Chinese students in Leuven and friend of Hergé. See: Tchang au pays du Lotus Bleu, Paris: Séguier, 1990, p. 45-56.

37 Jean DE MAEYER, "The Neo-Gothic in Belgium: Architecture of a Catholic Society", in: Jan DE MAEYER and Luc VERPOEST (eds), Gothic Revival. Religion, Architecture and Style in Western Europe 1815-1914 (KADOC Artes, 5), Leuven: Leuven University Press, 2000, p. 27-31; Jan DE MAEYER (ed.), De Sint-Lucasscholen en de neogotiek 1862-1914 (KADOC studies, 5), Leuven: Leuven University Press, 1988. 
project, and Brother Marès-Joseph (1838-1914) from the congregation of the Brothers of the Christian Schools, the pedagogue and inventor of a drawing method. St Luke Gothic Revival became the style of the Ultramontanes, the visualisation of faith in the struggle waged by Catholic tradition against Liberalism. Several other schools for young men from the working classes who wanted to develop skills and become Christian craftsman were founded in Tournai, Liège and Brussels. The St Luke Movement circulated its propaganda and achievements through journals and networks of Catholic artists, clerics and antiquarians. ${ }^{38}$ When Catholic governments ruled Belgium continuously from 1884 to 1914, St Luke Gothic became a national style that was not used only for churches, Catholic schools and the castles of the Ultramontanes, but also for official buildings, town halls, post offices and railway stations. ${ }^{39}$

One of Bethune's most remarkable works was the Benedictine abbey of Maredsous that was erected in the years 1872-90 as part of an ambitious project of monastic revival in Belgium. ${ }^{40}$ The new foundation was created by the abbey of Beuron and supported by Ultramontanes, especially industrialists from the Desclée and Hemptinne families who had relatives in the community. ${ }^{41}$ The reference style was thirteenth-century Gothic with typical lancet windows and ashlar masonry in the purest tradition of Pugin. Located on a hill and dominating a forest landscape, Maredsous looked like a medieval abbey. In 1898-1907, the abbey of Benedictine nuns at Maredret was built nearby by architect Auguste Van Assche (1826-1907), Bethune's right-hand man and a teacher at St Luke in Ghent. Both abbeys became a source of inspiration and a "place of pilgrimage" for architects who admired Baron Bethune and students of the St Luke schools. These included Alphonse De Moerloose 和美柏 (1858-1932), [277] the son of a Ghent ultramontane contractor, who studied architecture at St Luke in Ghent from 1876 to 1881 - the years Bethune, his master, was building Maredsous [Fig. 6 and Fig. 8] -, before joining the Congregation of the Immaculate Heart of Mary, being ordained as a priest in 1884 and sent to China, where he served as a missionary for 44 years (1885-1929).

After the Boxer Uprising (1899-1901) and the demolition of hundreds of churches, Father De Moerloose was given the opportunity to design new churches and became the most important church builder of his generation in China. ${ }^{42}$ At that time there were no missionaries with an architecture

38 The Guild of St Thomas and St Luke, created in 1863. The Bulletin des séances de la Gilde de Saint-Thomas et Saint-Luc (1864-1913), the Revue de l'Art Chrétien (1882-1914) and Bulletin des métiers d'art (1901-13).

39 Thomas Coomans, "Gothic Revival: Style and Ideology in Nineteenth-Century Belgium" and "Reconquering a Lost Visibility. Catholic Revival in Early Industrial Belgium", in: Jan DE MAEYER and Peter-Jan MARGRY (eds), Material Reform. Space and the Fabric of Buildings and Constructions The Dynamics of Religious Reform in Northern Europe 1780-1920 (Kadoc Artes, 19), Leuven: Leuven University Press (forthcoming).

40 Jules Helbig, Le Baron Bethune, fondateur des Écoles Saint-Luc. Étude biographique, Lille-Bruges : Société Saint-Augustin, 1906, p. 234-241; Jean VAN CLEVEN (dir.), Neogotiek in België, Tielt: Lannoo, 1994, p. 167199.

41 Daniel Misonne, En parcourant l'histoire de Maredsous, Denée: Éditions Maredsous, 2005, p. 10-21, 77-130.

42 Joseph VAn Hecken, “Alphonse Frédéric De Moerloose C.I.C.M. (1858-1932) et son œuvre d'architecte en Chine", Neue Zeitschrift für Missionswissenschaft / Nouvelle Revue de science missionnaire, 24/3, 1968, p. 161-178. 


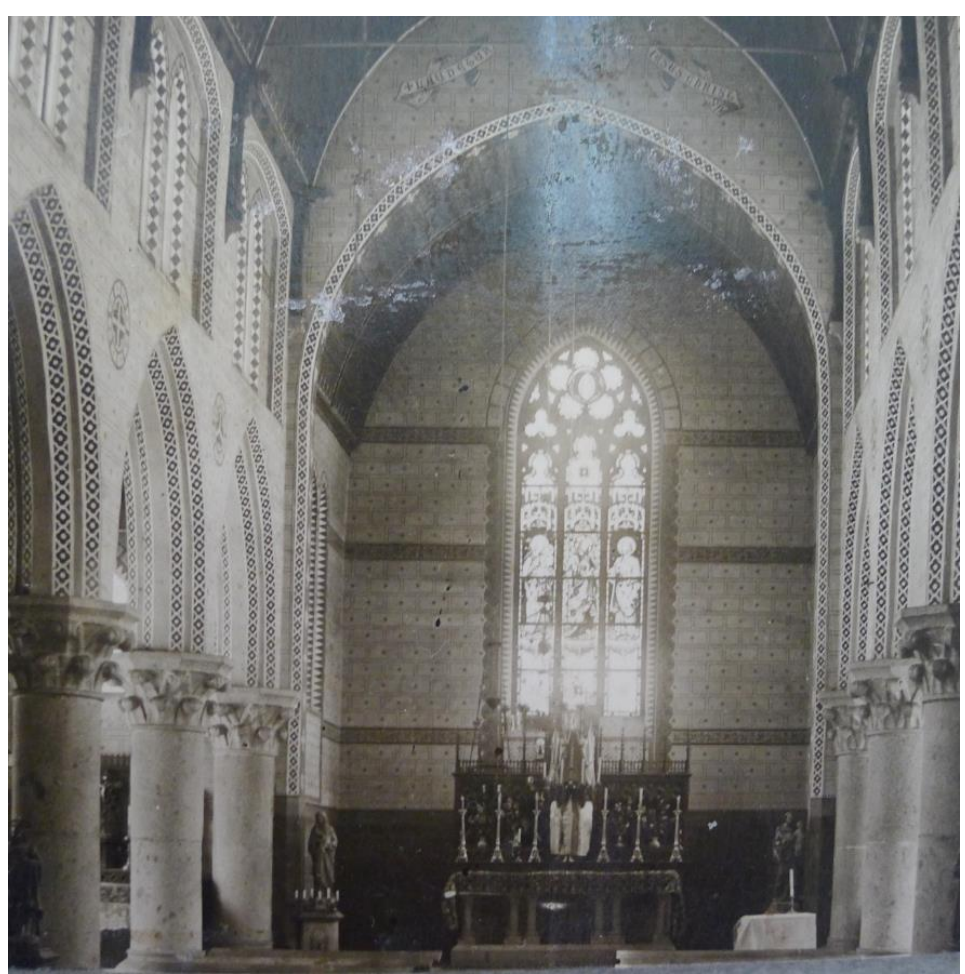

Fig. 3. Xiwanzi, chapel of the seminary in pure St Luke decorated style, A. De Moerloose, ca 1905 (KADOC, Archives CICM).

degree in China, only brother builders, usually carpenters, who were incapable of designing big and complex structures in masonry. ${ }^{43}$ De Moerloose's work included four cathedrals and dozens of churches for the Scheut Fathers, Lazarists and Jesuits, as well as a Trappist abbey, a pilgrimage church and two large seminaries. His buildings were all designed in accordance with the canon of St Luke: he exported the Gothic Revival of Pugin, Bethune and Van Assche to northern China and Inner Mongolia [Fig. 3 and Fig. 4]. ${ }^{44}$

Building Gothic churches in China was a big challenge because both the vocabulary of forms and construction techniques were completely unknown. With no craftsmen or labourers able to understand and execute his plans, De Moerloose had to train foremen and specialised teams who could go from site to site building an architecture completely unknown in rural China. ${ }^{45}$

43 Thomas CoOmans and Wei LuO, "Missionary-Builders: Scheut Fathers as Church Designers and Constructors in Northern China", in: Alexandre Tsung-ming CHEN (ed.), Catholicism's Encounters with China. 17th to 20th Century (Leuven Chinese Studies, 39), Leuven: Ferdinand Verbiest Institute, 2018, p. 333-364.

44 Thomas CoOMAns, "Pugin Worldwide. From Les Vrais Principes and the Belgian St Luke School to Northern China and Inner Mongolia", in: Timothy BritTAin-CATLIN, Jan De MAEYER and Martin Bressani (eds), Gothic Revival Worldwide: A.W.N. Pugin's Global Influence (KADOC Artes 16), Leuven, 2016, p. 156-171.

45 "Father de Moerloose greatly esteems the Chinese craftsman. Left to himself, poorly equipped, poorly trained, he is more or less content with 'bricolage'. Well trained, well equipped, he becomes a skillful stone and wood carver, a careful and conscientious mason. The architect must train his team himself; he can achieve better results than with European workers". From a visit of the Jesuit Father Émile Licent 桑志華 (1876-1952) to 


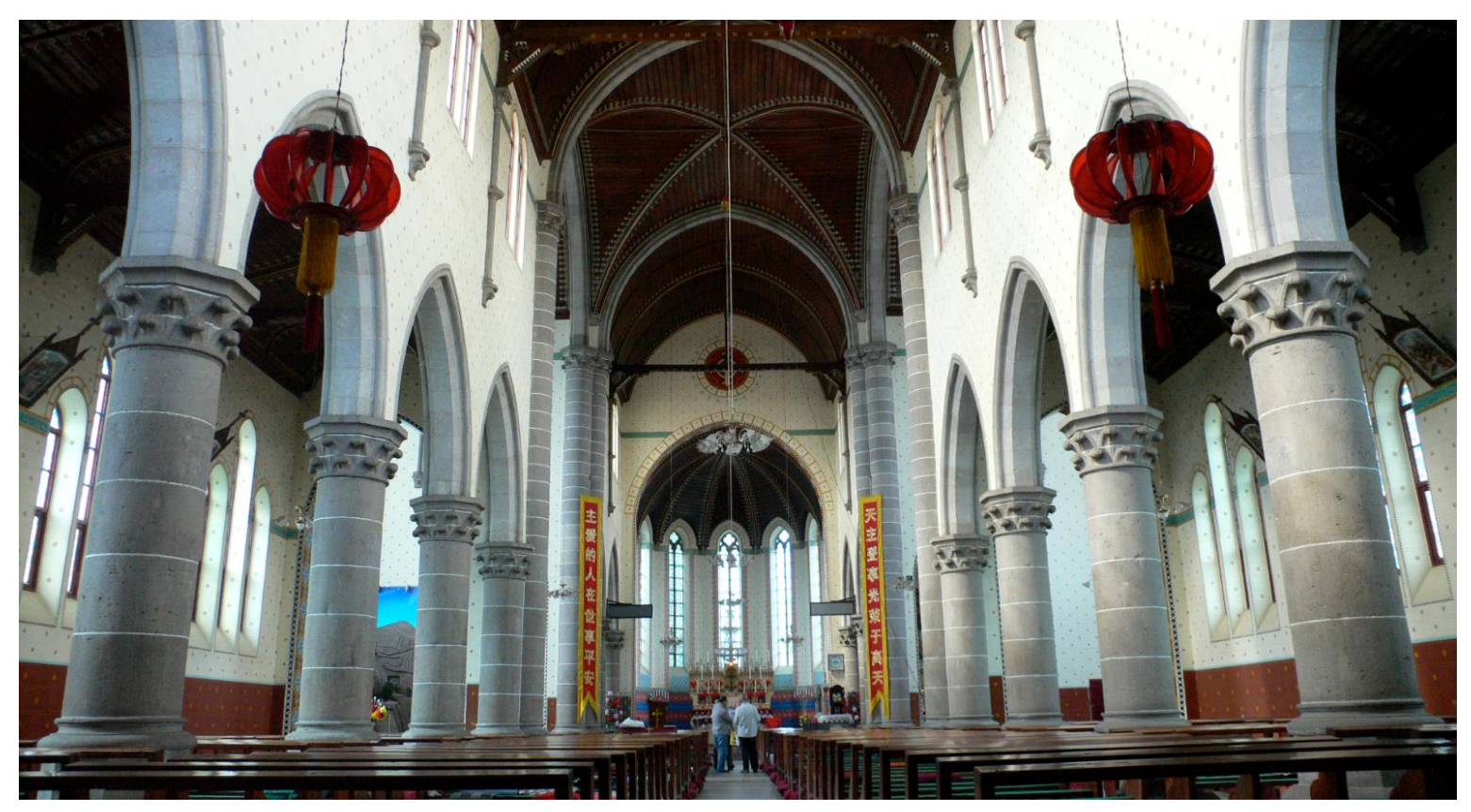

Fig. 4. Xuanhua, the best preserved church of A. De Moerloose, with a Maredsous-looking nave and wooden vaults, 1903-04 (THOC, May 2011).

He therefore contributed [278] to architectural and technical transfers between Europe and China. ${ }^{46}$ Gothic masonry architecture with vertical lines and towers contrasted entirely with the wooden structures and horizontal volumes of traditional Chinese architecture. At the end of his life, he also passed on his practical experience to other missionary-builders by contributing to a handbook for the building of churches in northern China. ${ }^{47}$ Consequently, the St Luke Gothic style became the style of Scheut in China: it was thus more than a nostalgia for architectural forms from Belgium, ${ }^{48}$

Yangjiaping: Émile LICENT, Comptes rendus de dix années, 1914-1923, de séjour et d'exploration dans le bassin du Fleuve Jaune, du Pai Ho et des autres tributaires du golfe du Pei Tcheu Ly, Tianjin: Librairie française, 1924, p. 429-430 (quote transtated from French).

46 Thomas Coomans, "East Meets West on the Construction Site. Churches in China, 1840s-1930s", Construction History, 33/2, 2018, p. 63-84; Thomas CoOMANS and Yitao XU 徐怡涛, “Gothic Churches in Early $20^{\text {th }}$ Century China: Adapting Western Building Techniques to Chinese Construction Tradition", in: Brian BowEN, Donald Friedman, Thomas Leslie and John OCHSENDORF (eds), Proceedings of the Fifth International Congress on Construction History. June 2015, Chicago, Illinois, Chicago: Society of Construction History, 2015, vol. 1, p. 523-530.

47 Thomas CoOmans 高曼士 and Yitao XU 徐怡涛, Bolai yu bentu-1926 nian faguo chuanjiao shi suo zhuan zhongguo beifang jiaotang yíngzao zhi yanjiu / 舶来与本土一—1926 年法国传教士所撰中国北方教堂营 造之研究 / Building Churches in Northern China. A 1926 Handbook in Context, Beijing: 知识产权出版社, 2016, 449 p.

48 Thomas Coomans and Wei Luo, "Mimesis, Nostalgia and Ideology: The Scheut Fathers and Home-CountryBased Church Design in China", in: History of the Catholic Church in China. From its beginning to the Scheut 


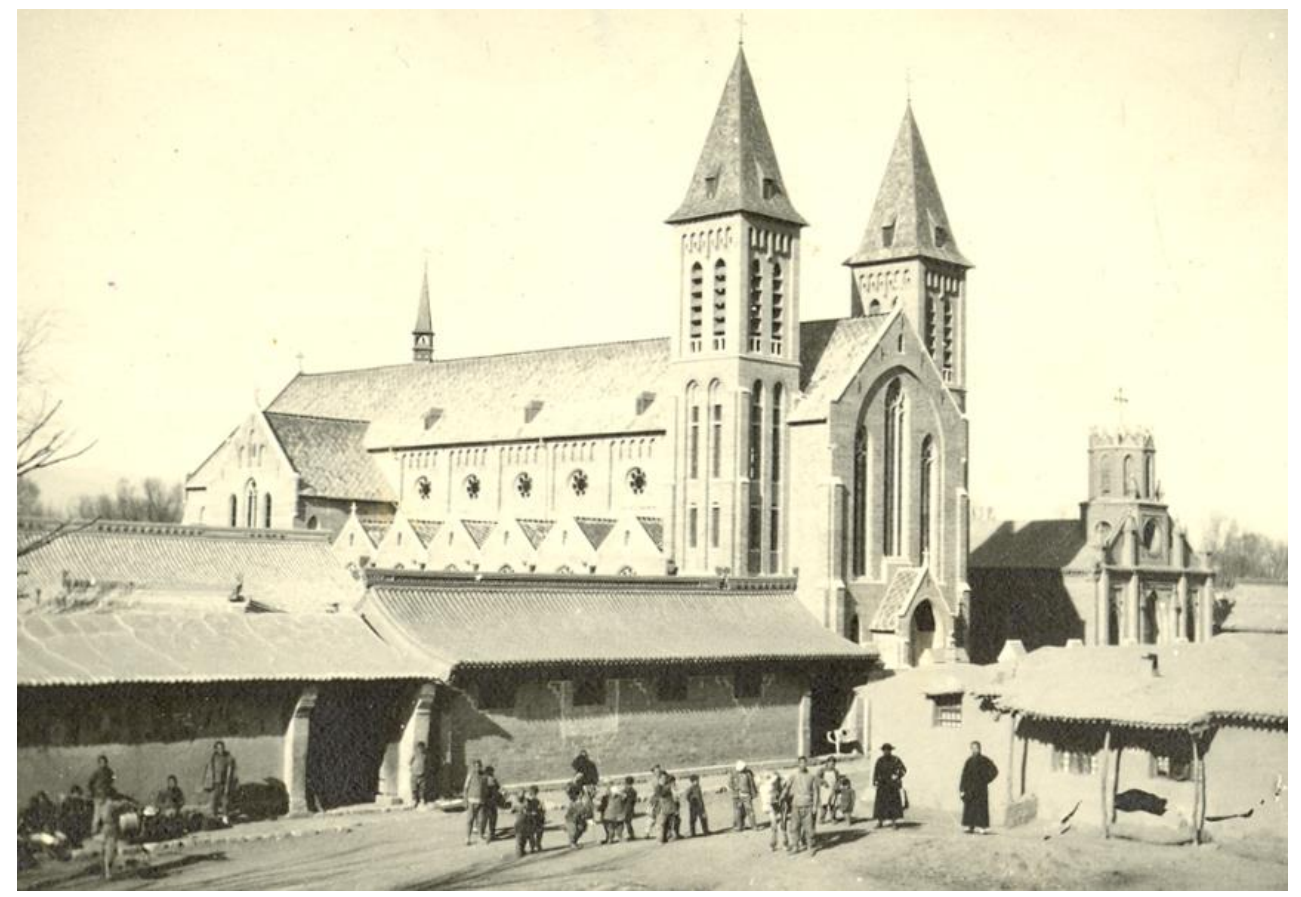

Fig. 5. Shuangshuzi, parish church by A. De Moerloose, with a Maredsous-looking façade, 1917 (KADOC, Archives CICM).

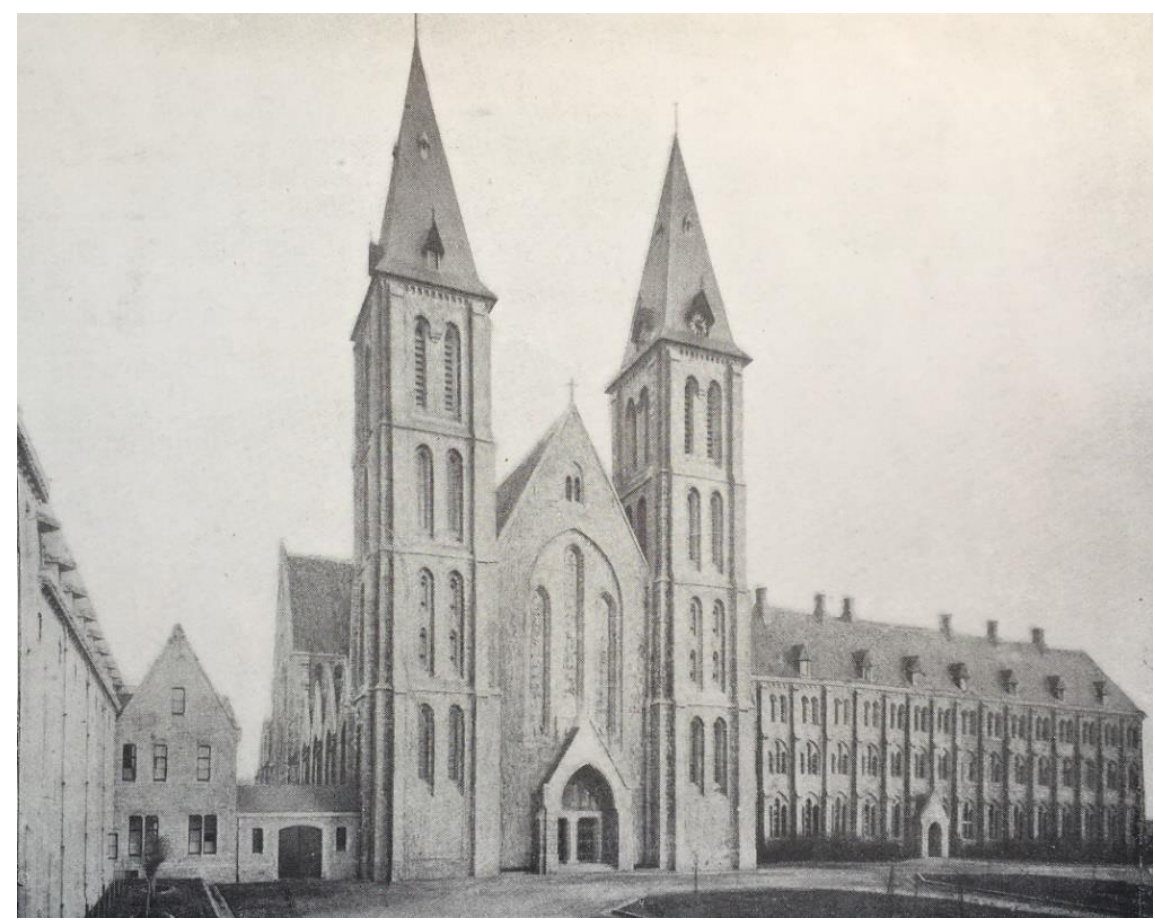

Fig. 6. Maredsous, abbey church designed by Baron Bethune, 1877-1887 (J. Helbig, Le Baron Bethune, 1906, PI. 31).

Fathers and 20th Century. Unveiling some less known Sources, Sounds and Pictures (Leuven Chinese Studies, 29), Leuven: Ferdinand Verbiest Institute, 2015, p. 495-522. 
but a style that expressed the Catholic ultramontane worldview of missionaries who were faithful to the Pope, in the service of Christ, and promoting the only revealed Truth. ${ }^{49}$

Building was one thing, but designing was another. How did Father De Moerloose, who had been disconnected from any significant architectural activity since 1884, not to mention the evolution of architecture in Europe, find inspiration for his designs during his active period in China between 1899 and 1929? His works themselves provide the answer: he reproduced what he had learned during his student years, combining the drawing and design methods of the Brothers of the Christian Schools and the models of his two masters Jean Baptiste Bethune and Auguste Van Assche. ${ }^{50}$ Furthermore, [279] he remained in contact with St Luke, through his family and especially his brother-in-law, architect Modeste de Noyette (1847-1923), who sent him pictures of his own churches and Belgian architectural magazines. De Moerloose trained Chinese painters to execute St Luke decorative mural painting, but ordered Neo-Gothic stained-glass windows from Ghent and had them sent to China. All in all, De Moerloose's main reference was and remained St Luke [Fig. 3].

The abbey church of Maredsous, which was under construction when Father De Moerloose was a student and soon became an archetype of St Luke Gothic, was one of his favourite models when it came to designing important churches in China. This filiation has been identified in at least four cases: none of these is a copy of Maredsous, but parts of Maredsous were combined with parts of other churches by Bethune and his epigones to create new designs (see Table 3). Only the church of Xuanhua has been conserved, showing similar wooden vaults on the nave and crossing as Maredsous [Fig. 4]. ${ }^{51}$ The church of Shuangshuzi burned down in 2009, with the exception of its two towers that formed part of a Maredsous-like façade, as can be seen in old photographs [Fig. 5 and Fig. 6]. The Gothic project for the pilgrimage basilica of Shanghai, which was designed half a century later than Maredsous, was more monumental [Fig. 7 and Fig. 8], but was never built because the Jesuits wanted a Romanesque church. ${ }^{52}$ When he was asked to design an abbey church for the Trappist abbey of Yangjiaping, the first contemplative abbey in China located about 200 kilometres north-west of Beijing, Father De Moerloose could only think of Maredsous [Fig. 9]. The austere church has a similar vaulting system and small gables along the aisles to Maredsous, but had neither transept nor towers and was completely whitewashed inside. In 1910, Father De Moerloose left the congregation of the Immaculate Heart of Mary and became a secular priest incardinated in the vicariate apostolic

49 Thomas CoOmans, "Pugin Worldwide..." (see n. 44), p. 167-171; Anthony E. Clark, China Gothic. The Bishop of Beijing and His Cathedral, Seattle: University of Washington Press, 2019, p. 54-56.

50 Thomas CoOMANS, "Sint-Lucasneogotiek in Noord-China: Alphonse De Moerloose, missionaris en architect", M\&L. Monumenten, Landschappen en Archeologie, 32/5, 2013, p. 6-33.

51 Thomas CoOMANS and Wei LuO, "Exporting Flemish Gothic Architecture to China: Meaning and Context of the Churches of Shebiya (Inner Mongolia) and Xuanhua (Hebei) built by Missionary-Architect Alphonse De Moerloose in 1903-1906", Relicta. Heritage Research in Flanders, 9, 2012, p. 219-262.

52 Thomas CoOmans, "Notre-Dame de Sheshan à Shanghai, basilique des Jésuites français en Chine, 1867-1936", Bulletin monumental, 176/2, 2018, p. 129-156 ; ID, 高曼士, Sheshan jiaotang jianzao de lishi xun zong 余山 教堂建造的历史寻踪 [The Construction History of Sheshan Church], Shanghai: Tongji University Press (2022). 


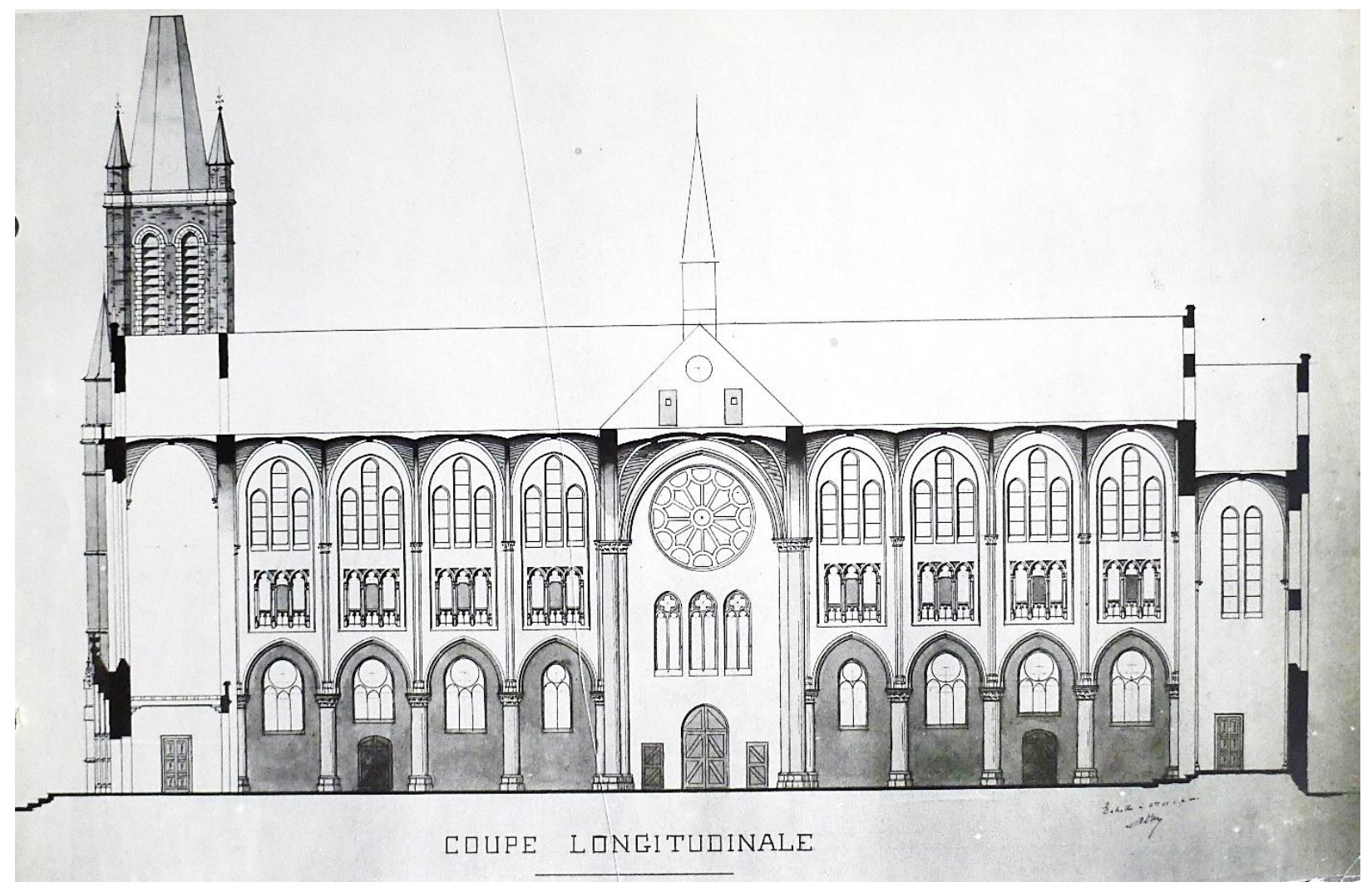

Fig. 7. Shanghai, unbuilt project for the basilica of Sheshan, A. De Moerloose, 1920 (KADOC, Archives CICM).

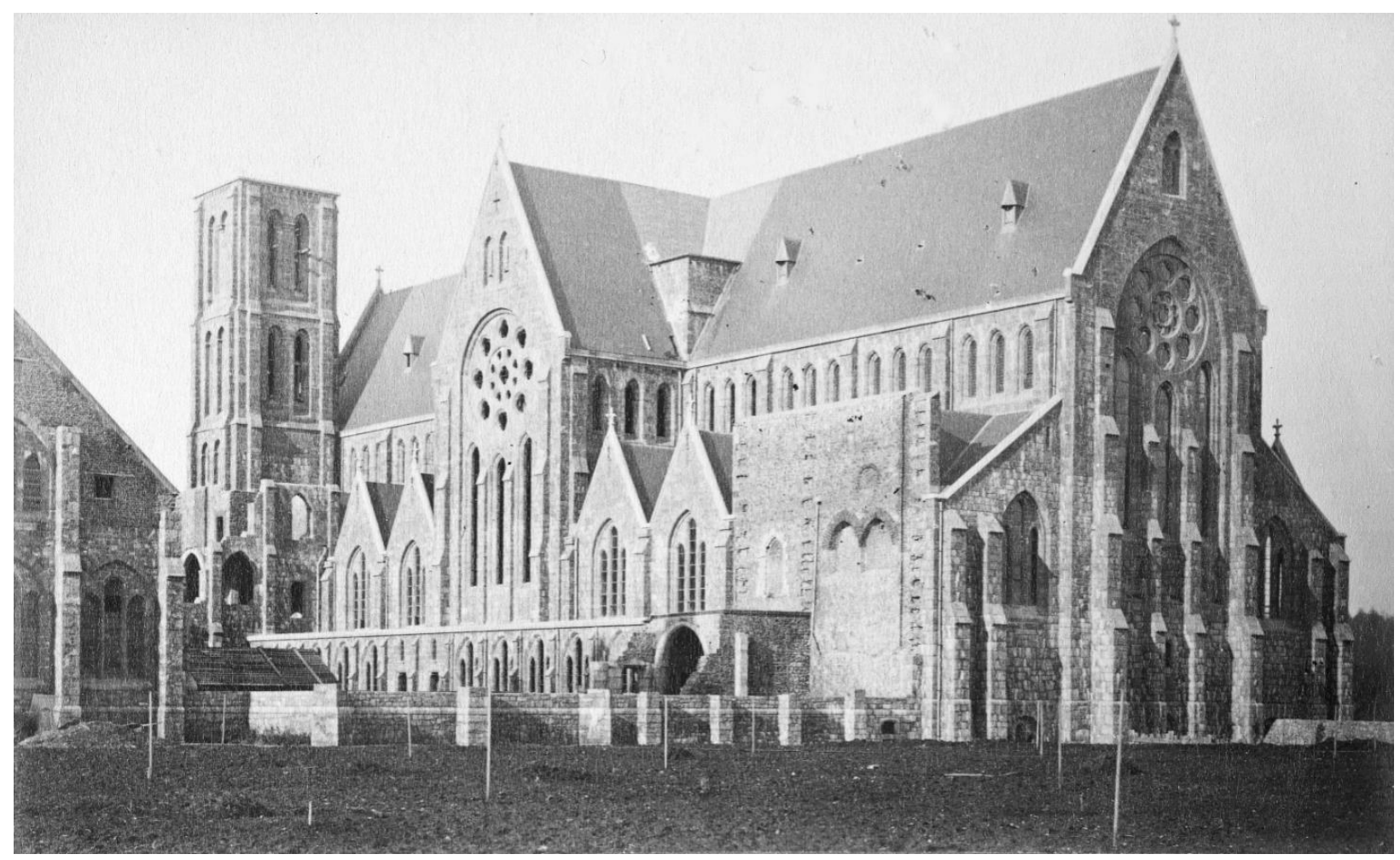

Fig. 8. Maredsous, abbey church under construction, ca 1880 (Archives of the Abbey of Maredsous). 
Table 3. Churches in China with architectural elements from Maredsous designed by Father Alphonse De Moerloose.

\begin{tabular}{|c|c|c|c|}
\hline $\begin{array}{c}\text { CHURCH IN } \\
\text { CHINA }\end{array}$ & $\begin{array}{l}\text { DATES } \\
\text { AND } \\
\text { STATE }\end{array}$ & $\begin{array}{c}\text { ELEMENTS FROM } \\
\text { MAREDSOUS }\end{array}$ & $\begin{array}{c}\text { ELEMENTS FROM } \\
\text { OTHER ST LUKE } \\
\text { GOTHIC CHURCHES }\end{array}$ \\
\hline $\begin{array}{l}\text { Xuanhua 宣化 } \\
\text { (Hebei), Holy Cross } \\
\text { church, built for } \\
\text { French Lazarists, } \\
\text { cathedral in } 1926\end{array}$ & $\begin{array}{l}\text { 1903-04 } \\
\text { still in } \\
\text { existence }\end{array}$ & $\begin{array}{l}\text { crossing, columns and } \\
\text { capitals of the nave, } \\
\text { wooden vaults of the } \\
\text { nave and crossing }\end{array}$ & $\begin{array}{l}\text { plan, choir and apse from } \\
\text { St Joseph's Church, } \\
\text { Roubaix, designed by } \\
\text { Bethune in } 1875-78\end{array}$ \\
\hline $\begin{array}{l}\text { Yangjiaping 禓家坪, } \\
\text { Huailai 懷來 (Hebei), } \\
\text { abbey church, French } \\
\text { Trappist abbey of } \\
\text { Consolation 神慰院 }\end{array}$ & $\begin{array}{l}1903 \\
\text { demolished }\end{array}$ & $\begin{array}{l}\text { columns and capitals, } \\
\text { right apse, wooden } \\
\text { vaults, roofs and } \\
\text { gables on the aisles, } \\
\text { rose window, lancet }\end{array}$ & \\
\hline $\begin{array}{l}\text { Shuangshuzi 雙樹 } \\
\text { 子 (Hebei), parish } \\
\text { church for a Chinese } \\
\text { Christian village, } \\
\text { financed by a wealthy } \\
\text { parishioner }\end{array}$ & $\begin{array}{l}1917 \\
\text { demolished } \\
\text { in } 2009, \\
\text { the towers } \\
\text { remain }\end{array}$ & $\begin{array}{l}\text { main façade with two } \\
\text { towers, central window } \\
\text { and porch, roofs and } \\
\text { gables on the aisles }\end{array}$ & $\begin{array}{l}\text { clerestory (round } \\
\text { windows) and nave, from } \\
\text { 13th-century St } \\
\text { Christophe Church, Liège, } \\
\text { studied / restored by Van } \\
\text { Assche, 1877-97 }\end{array}$ \\
\hline $\begin{array}{l}\text { Shanghai 上海, } \\
\text { basilica of Our Lady } \\
\text { of Sheshan 余山聖 } \\
\text { 母教堂, for French } \\
\text { Jesuits }\end{array}$ & $\begin{array}{l}1920 \\
\text { unbuilt } \\
\text { Gothic } \\
\text { project }\end{array}$ & $\begin{array}{l}\text { main façade with two } \\
\text { towers, right apse, } \\
\text { nave and choir of equal } \\
\text { length, triplet windows }\end{array}$ & $\begin{array}{l}\text { plan from Arlon, St } \\
\text { Donat's Church, by } \\
\text { Edouard Van Gheluwe } \\
\text { and Modeste de Noyette, } \\
1904-07\end{array}$ \\
\hline
\end{tabular}

of Beijing. He settled in Yangjiaping where he had a studio and lived a kind of semi-monastic life alternating with trips to the construction sites as well as to Beijing, Tianjin and Shanghai. [280] Criticism was levelled at the style and churches designed by Father De Moerloose when Mgr Celso Costanini arrived in China with the mission to implement the inculturation policy decided by the Holy See. Father De Moerloose was obviously unaware of the complexity of this evolution and viewed it merely from an architectural perspective. As an Ultramontane, he remained convinced that Gothic was the only valid style for Catholic churches anywhere in the world. In two letters to a friend, he wrote: "Monsignor the Delegate [Celso Costantini] especially dislikes Gothic; as with all Italians, his reference is St John of Lateran", "I travelled for ten days with the Apostolic Delegate to see newly built churches. [...] The wish of the Propaganda Fide is that one should build in the Chinese style so that people could not claim that the Christian religion is European [...]". 53

53 Leuven, KADOC, Archives of the Congregation of the Immaculate Heart of Mary, T.1.a.14.3.2. Letters from A. De Moerloose to Father Karel Van de Vyvere, 28 August 1924 and 19 February 1925. Quotes translated from Dutch. See also Th. CoomAns and W. LuO, "Exporting Flemish Gothic Architecture to China..." (see n. 51), p. 251-252. 


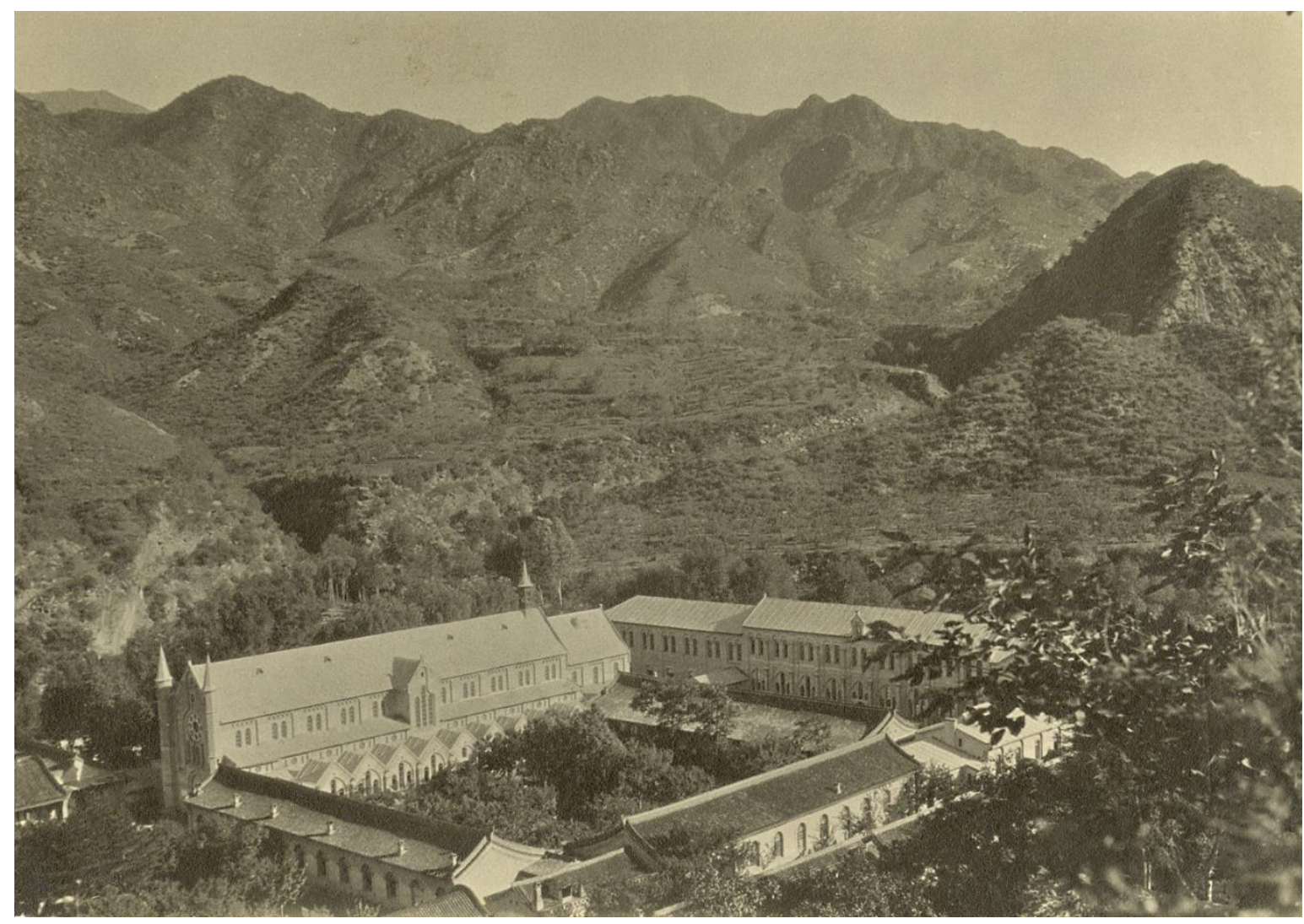

Fig. 9. Yangjiaping, Trappist abbey of Consolation, church by A. De Moerloose, 1917 (KADOC, Archives CICM).

[281] Father De Moerloose, however, also failed to understand that neo-Gothic was no longer in favour with the Church in post-war Europe and that even the St Luke schools had abandoned the Gothic paradigm in Belgium.

Father De Moerloose returned to Belgium in December 1929 and passed away in 1932. We do not know if he visited Maredsous and Saint-André but a connection with Dom Pierre-Célestin Lou is worthy of mention. In 1920, Lu Zhenxiang erected a mausoleum-chapel for his parents in the Christian cemetery of Zhalan 栅栏 in Beijing, close to the tombs of Father Verbiest and other seventeenth- and eighteenth-century Jesuits. Among Confucian virtues, honouring the memory of parents is a sacred duty. The mausoleum was designed by architect Gustave Volckaert 華立慧 (18881978), a nephew of Alphonse De Moerloose, who was working in Tianjin for the Belgian company Crédit Foncier d'Extrême-Orient at the time. ${ }^{54}$

54 Gustave Volckaert and $\mathrm{Lu}$ were friends, as is apparent from Lu's letters (Montreux, family archives Jean Volckaert). In Hong Kong, Volckaert designed several buildings institutes (Maryknoll Sisters, Sisters of St Paul of Chartres and Trappists abbey of Joy, Lantao). See: Thomas CoOMANS and Leung-kwok Prudence LAU, "Les tribulations d'un architecte belge en Chine: Gustave Volckaert, au service du Crédit Foncier d'ExtrêmeOrient, 1914-1954", Revue Belge d'Archéologie et d'Histoire de l'Art, 81, 2012, p. 129-153. 


\section{AMIDST THE WEB OF SINICISATION: Dom Adelbert Gresnigt under Monsignor Celso Costantini}

As a part of his mission to indiginise Christianity in China, Mgr Celso Costantini wanted churches in the Chinese style, with localised art and furniture, served by indigenous bishops and priests. In several articles, he attacked Western styles, especially Gothic, using aesthetic and theological arguments. ${ }^{55}$ As far as he was concerned, Christian art was a question of spirit rather than merely the use of local forms and ornaments. The field of architecture in Republican China was, however, much more complex than a mere question of forms and spirit because the choice of precise architectural styles [282] was part of a search for societal modernisation and a new identity. ${ }^{56}$ Mgr Costantini faced three challenges with regard to shaping and affirming the identity of Chinese Catholics through architecture. ${ }^{57}$ First, French missionaries - who shared Father De Moerloose's worldviews continued to promote Western styles, believing that this was what most Chinese Catholics wanted, and reproved all attempts to integrate Chinese decoration into churches. Second, Protestant missions were already building churches and university campuses in the Chinese style and were engaged in the Chinese architectural Renaissance movement promoted by the Kuomintang. ${ }^{58}$ Third, Chinese Catholics were seeking to define their own identity in a Chinese society undergoing transformation.

The Apostolic Delegate was keen to commission Chinese artists to create the "Sino-Christian style" because he was convinced that only natives could express the deep Chinese soul, whereas Western artists could only produce "chinoiserie". When it came to architecture, however, he was unable to find any authentic Chinese Catholic architects. Because of the urgent situation, Mgr Costantini involved Dom Adelbert Gresnigt 葛利斯 (1877-1956), a Dutchman and Benedictine monk from Maredsous, in his project. In the section that follows, we will analyse the "web of Sinicisation" in which Dom Gresnigt found himself somewhat in spite of himself and see how this relate to the Benedictine and Belgian missionary architectural projects in China mentioned in the two first parts of this article.

55 Celso Costantini, "Proper Style of Church Architecture for the Chinese Mission (letter of the Apostolic Delegate to China Addressed to the American and Irish Missionaries)", The Ecclesiastical Review, 69/3, September 1923, p. 288-293. This key article, has been reprinted and translated in several journals in the 1920s and 1930s. See also: Celso CostantinI, "Le problème de la culture missionnaire et la Chine aujourd'hui," Collectanea Commissionis synodalis/Digest of the Synodal Commission, 4, 1931, p. 1089-1112.

56 Haiqing LI and Xiaoqian WANG, The Art of Architectural Integration of Chinese and Western, Beijing: China Architecture \& Building Press, 2015.

57 Thomas CoomAns, "The 'Sino-Christian Style': A Major Tool for Architectural Indigenization”, in: Yangwen ZHENG (ed.), Sinicizing Christianity (Studies in Christian Mission, 49), Leiden-Boston: Brill, 2017, p. 197-232 (esp. 202-209).

58 Jeffrey W. CODY, "American Geometries and the Architecture of Christian Campuses in China", in: Daniel H. BAYS and Ellen WIDMER (eds), China's Christian Colleges: Cross-Cultural Connections, 1900-1950, Stanford: Stanford University Press, 2009, p. 27-56; Jeffrey W. CODY, "Striking a Harmonious Chord: Foreign Missionaries and Chinese-style Buildings, 1911-1949," Architronic, 1996, V5n3. 
At first glance Mgr Costantini's choice may seem surprising because Dom Gresnigt, aged 49, was neither a missionary nor an architect, but a painter and sculptor who had been trained by Dom Desiderius Lenz (1832-1928) at the Beuron Art School and had worked exclusively for the Benedictine order on the decoration of the crypt of St Benedict at Monte Cassino, the church of the monastery [283] of São Bento in São Paulo, and the church of St Anselm in the Bronx, New York. ${ }^{59}$ However, Mgr Costantini and Dom Gresnigt had known each other for more than fifteen years and shared the same artistic and religious values. ${ }^{60}$ The former knew the latter would be obedient and dedicate himself entirely to his mission, whereas a lay architect might have different views and personal ambitions. As a close collaborator of the Apostolic Delegate in China, from March 1927 to January 1932, he was associated with the discussion around inculturation in China and became the official reference for artistic matters. Dom Gresnigt, who was a modest and introverted person, felt uncomfortable with such a high profile and that so much was expected of him, for example: "it is hoped that under his leadership the Benedictines in China may do for Chinese art and architecture what the early Benedictines did centuries ago for the art and architecture of medieval Europe". ${ }^{61}$ From an almost anonymous artist, Mgr Costantini projected Dom Gresnigt to the front of the stage as long as he needed him, but when the American Benedictines withdrew from the Catholic University of Peking, he was used for fundraising tours in the USA and eventually commissioned to paint in the Pontificio Collegio Olandese in Rome, far from the spotlight. The abbot of Maredsous was decidedly unhappy with how the situation evolved, all the more so because the American abbeys had not paid Father Gresnigt's wages. ${ }^{62}$

On 16 August 1926, Archabbot Aurelius Stelhe (1877-1930), Chancellor of the Catholic University of Peking, wrote to Dom Célestin Golenvaux (1879-1952), Abbot of Maredsous, signifying his formal acceptance of the services of Dom Adelbert Gresnigt. The two men had come to an agreement as to indemnities of 10 US \$ per working [284] day to be paid by the American Cassinese Congregation to the abbey of Maredsous during Dom Adelbert's sojourn in China, which was initially planned for two years. ${ }^{63}$ This step was taken in deference to the wishes of Cardinal Willem van Rossum (1854-1932), Prefect of the Propaganda Fide. On 28 October 1926, before his

59 Félix STANDAERT, L'école de Beuron. Un essai de renouveau de l'art chrétien à la fin du XIXe siècle, Denée: Éditions de Maredsous, 2011, p. 29-35.

60 Mgr Costantini, who was himself an artist, liked the art of Beuron: Celso CosTANTINI, "L'arte benedettina", Emporium, Bergamo: Istituto italiano d'arti grafiche, 33/194, 1911, p. 83-100.

61 Quote from "Chronicle", Bulletin of the Catholic University of Peking, 1, September 1926, p. 69-70. See also: Albert Franz COCHRANE, "An artist-monk who is also an architect. In China he is working to develop a SinoChristian type of ecclesiology", Boston Evening Transcript, Saturday 20 August 1932, p. 6.

62 Archives of the abbey of Maredsous, archive Dom Gresnigt, correspondence. Letter of Abbot Golenvaux to Dom Gresnigt, 22 November 1933: “Je ne puis oublier la pénible impression que m'ont causée les grandes déceptions de Péking où, après un contrat formulé très nettement et signé, l'Abbaye de Maredsous s'est vue frustrée de tout le fruit de votre travail".

63 Archives of the abbey of Maredsous, Correspondence Abbot Célestin Golenvaux, 1.1.9. It seems that very little of this stipendium was paid. In a letter to Abbot Golenvaux, 5 September 1927, Archabbot Stelhe writes: "I often think back to the great monastery of Maredsous. I wish had a Desclee or two, who would put up a building for us here in China, where 275 pupils have already applied for next scholastic year". 


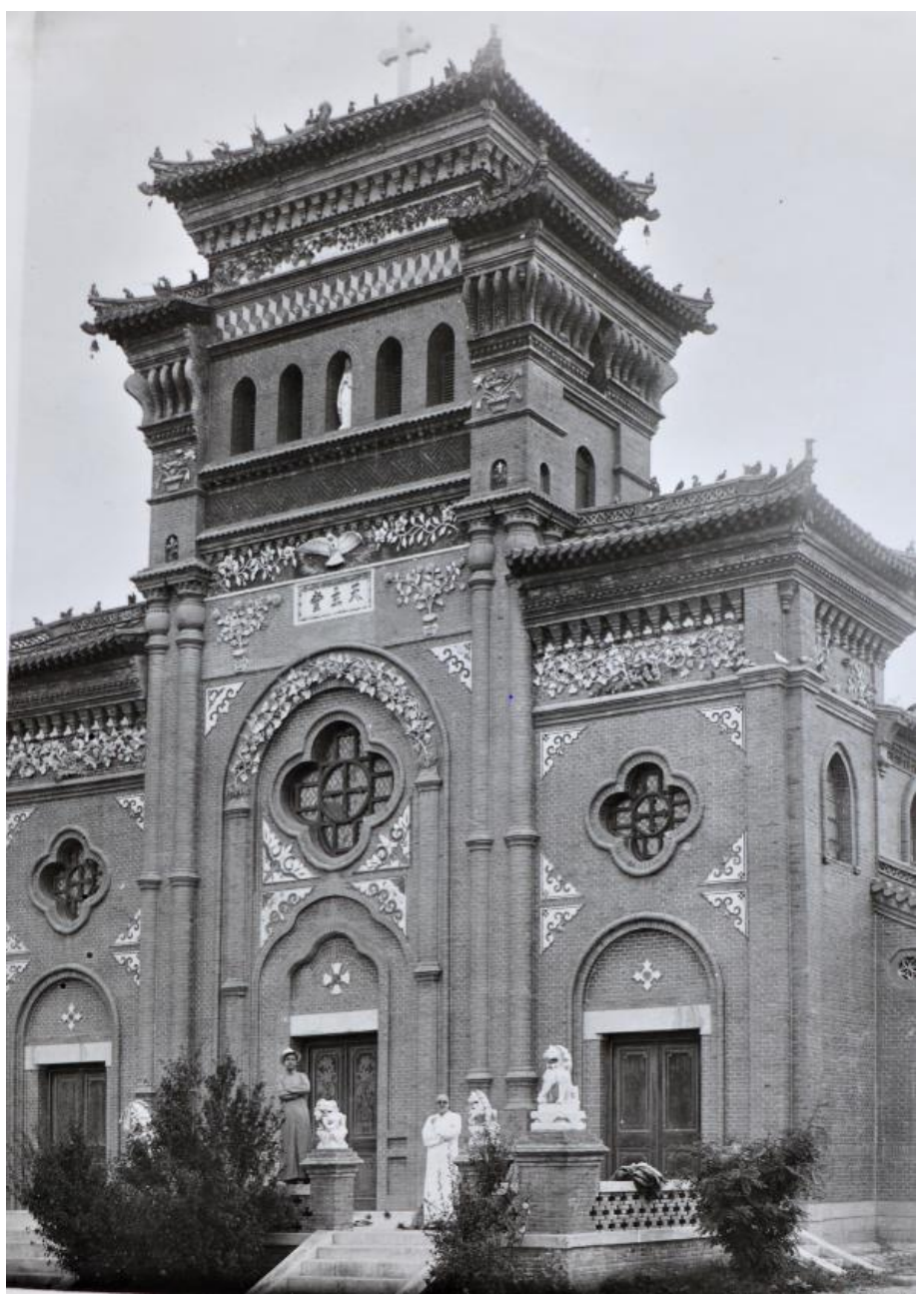

Fig. 10. Anguo, cathedral of Mgr Melchior Sun Dezhen, façade based on a sketch of A. Gresnigt, 1927-33

(Archives of the Society of Auxiliaries of the Mission).

trip to China, Dom Gresnigt attended the episcopal consecration of the six first Chinese bishops - two of whom he would later work for in China - by Pope Pius XI in the basilica of St Peter's in Rome. This pivotal moment in the history of the Catholic Church in China was also attended by two of its major artisans, Father Lebbe and Mgr Costantini. On 8 November, Dom Gresnigt had a meeting with Cardinal van Rossum and on 15 November he was received in private audience by Pope Pius XI. ${ }^{64}$ This immersion at the highest level of Catholic hierarchy gave the monk from Maredsous a name and prestige as well as putting him under great pressure as he knew almost nothing about the China mission, Chinese art or architecture. Dom Gresnigt arrived in Beijing on 5 March 1927 and lived with the American Benedictine community of the Catholic University of Peking, led by Prior Ildefonse Brandstetter, in Tao Beile Fu mansion 涛贝勒府, the residence of an uncle of the last emperor in Xicheng district. Here too, he was at heart of the "web of Sinicisation", entrusted with designing the most ambitious Catholic university project in China.

64 Bulletin of the Catholic University of Peking, 2, March 1927, p. 53-54. 
As soon as Father Vincent Lebbe returned to China in April 1927, he gave several lectures to the students of the Catholic University of Peking. ${ }^{65}$ Gresnigt and the two Lebbe brothers were childhood friends, having met in 1893 at Maredsous, where Gresnigt and Béda Lebbe eventually entered the community in 1896 and 1897, while Vincent Lebbe joined the Congregation of the Mission with the aim of going to China. Father Lebbe was now a naturalised Chinese citizen and was helping Mgr Melchior Sun Dezhen 孫德楨 (1869-1951), one of the newly consecrated Chinese bishops, to establish the vicariate [285] apostolic of Anguo. Father Lebbe asked his friend to come up with a design to turn the Gothic-style church of Gaojiazhuang 高家莊 (present Gaozhuang Zhangcun 高莊 張村), then his parish church, into a Chinese-style church. Jean-Paul Wiest has shown how this design, as well as drawings for a high altar and episcopal throne, were eventually used for the cathedral that Mgr Sun built in Anguo 安國 [Fig. 10]. ${ }^{66}$ In Beijing, Dom Gresnigt also met Dom Jean Joliet and Dom Pius de Cocquéau who joined the Benedictine community from July 1927 to April 1928 and undoubtedly exchanged views on monastic and Chinese architecture before going to Sichuan and founding the Priory of Xishan.

How did Dom Gresnigt, who had no knowledge at all of China, its culture or its traditional architecture, become the creator of the Sino-Christian architectural paradigm? We do not know who introduced him to Chinese architecture, the places he visited both in and beyond Beijing, which books he read, or how he came into contact with Chinese and Western professionals. An article from 1929 depicts him as an autodidact, which is unlikely since he lived in the intellectual milieu of the Catholic University of Peking, but nonetheless contributed to the myth of the artist-monk. ${ }^{67}$ Dom Gresnigt published two articles that expressed his admiration for the deep religious character of Chinese architecture, proved his knowledge of the architectural principles of Chinese architecture and refuted the objections of opponents to indigenisation. ${ }^{68}$ As far we can deduce from the scarce archives, Dom Gresnigt was assisted by a Chinese architect whose name and origin remain unknown. Architect Paul Muller 保罗・慕乐 (1891- ?), who worked at the Tianjin office of the French construction firm Brossard-Mopin 永和营造公司, designed the technical plans and concrete structures of the seminary

65 Father Lebbe visited the university on 24 August, 1 November and 29 December 1928. Bulletin of the Catholic University of Peking, 6, July 1929, p. 127, 129, 131.

66 Jean-Paul WIEST, "Le père Lebbe et son église de style chinois", in: Arnaud JOIN-LAMBERT, Paul SERVAIS, Chung Heng SHEN and Éric DE PAYEN (eds), Vincent Lebbe et son héritage, Louvain-la-Neuve, 2017, p. 85106.

67 Sylvester Healy, "The Plans of the New University Building", Bulletin of the Catholic University of Peking, 6, July 1929, p. 3-12 (quote p. 5).

68 Adelbert GRESNIGT, "Chinese Architecture", Bulletin of the Catholic University of Peking, 4, 1928, p. 33-45 (the same in Journal of the Association of Chinese and American Engineers, 12, 1931, p. 3-14); translation: ID., "Architecture Chinoise", Collectanea Commissionis synodalis/Digest of the Synodal Commission, 5, 1932, p. 418-437. Adelbert GRESNIGT, "Reflections on Chinese Architecture", Bulletin of the Catholic University of Peking, 8, 1931, p. 3-26; translation: ID., "Réflexions sur l'architecture Chinoise," Collectanea Commissionis synodalis/Digest of the Synodal Commission, 5, 1932, p. 438-469. 
Table 4 - Buildings designed by Dom Adelbert Gresnigt in China [287]

\begin{tabular}{|c|c|c|}
\hline PLACE / INSTITUTION & DATES & PEOPLE INVOLVED \\
\hline $\begin{array}{l}\text { Beijing: Fu Jen Catholic University } \\
\text { of Peking 辅仁大学 - built }\end{array}$ & $\begin{array}{l}\text { 1927-29: design; } \\
\text { 1929-30: } \\
\text { construction }\end{array}$ & $\begin{array}{l}\text { Mgr Celso Costantini, apostolic delegate; } \\
\text { Benedictines, American Cassinese Congregation; } \\
\text { Propaganda Fide }\end{array}$ \\
\hline $\begin{array}{l}\text { Aberdeen 香港仔 (Hong Kong): } \\
\text { South China Regional Seminary - } \\
\text { partially built }\end{array}$ & $\begin{array}{l}\text { 1927-29: design; } \\
\text { 1930-31: } \\
\text { construction }\end{array}$ & $\begin{array}{l}\text { Mgr Celso Costantini, apostolic delegate; Mgr Enrique } \\
\text { Valtorta P.I.M.E. 恩理覺, vicar apostolic of Hong } \\
\text { Kong }\end{array}$ \\
\hline $\begin{array}{l}\text { Xuanhua 宣化 (Hebei): Seminary, } \\
\text { Congregation of the Disciples of } \\
\text { the Lord (CDD) } \\
\text { 主徒會 } \\
\text { - built (partially demolished) }\end{array}$ & $\begin{array}{l}\text { 1928-31: design; } \\
\text { 1935: completed }\end{array}$ & $\begin{array}{l}\text { Mgr Celso Costantini, apostolic delegate, founder of } \\
\text { CDD in 1928; Mgr Peter Cheng Youxian 程伯多禄, } \\
\text { vicar apostolic of Xuanhua }\end{array}$ \\
\hline $\begin{array}{l}\text { Kaifeng 開封 (Henan): Regional } \\
\text { Seminary of Central China - built }\end{array}$ & $\begin{array}{l}\text { 1929: design; 1932: } \\
\text { completed }\end{array}$ & $\begin{array}{l}\text { Mgr Celso Costantini, apostolic delegate; Giuseppe } \\
\text { Tacconi O.F.M. 谭维新, vicar apostolic of Kaifeng }\end{array}$ \\
\hline $\begin{array}{l}\text { Anguo 安國 (Hebei): Cathedral } \\
\text { - built (demolished) }\end{array}$ & $\begin{array}{l}\text { 1927: design church } \\
\text { of Gaojiazhuang } \\
\text { 高家莊; } \\
\text { 1933: cathedral }\end{array}$ & $\begin{array}{l}\text { Mgr Melchior Sun Dezhen C.M. 孫德楨, vicar } \\
\text { apostolic of Anguo; Father Vincent Lebbe }\end{array}$ \\
\hline $\begin{array}{l}\text { Haimen 海門 (Jiangsu): Cathedral } \\
\text { - unbuilt }\end{array}$ & undated plans & $\begin{array}{l}\text { Mgr Simon Zhu Kaimin S.J. 朱开敏, vicar apostolic } \\
\text { of Haimen }\end{array}$ \\
\hline $\begin{array}{l}\text { Kowloon Tong 九龍塘 (Hong } \\
\text { Kong): St Teresa Church } \\
\text { - built }\end{array}$ & $\begin{array}{l}\text { 1928: sketches; } \\
\text { 1930: plans; 1932: } \\
\text { completed }\end{array}$ & $\begin{array}{l}\text { Parishioners, Catholic Portuguese; Joseph Chanatong } \\
\text { 陳阿堂, Catholic contractor; Mgr Enrique Valtorta } \\
\text { P.I.M.E. 恩理覺, vicar apostolic of Hong Kong }\end{array}$ \\
\hline
\end{tabular}

buildings in Beijing, Kaifeng [286] and Xuanhua, ${ }^{69}$ while the Hong Kong-registered architectural firm Little, Adams \& Wood made all the plans for the Regional Seminary in Aberdeen. ${ }^{70}$

Dom Gresnigt designed four key buildings that were part of the Catholic Church in China's new inculturation policy, as promoted by Mgr Costantini. In addition to the Catholic University of Peking, his masterwork, there were two regional seminaries for the education of Chinese priests in Kaifeng and Hong Kong, as well as the seminary of the Disciples of the Lord in Xuanhua, the first full Chinese religious congregation founded by Mgr Costantini in 1928 (see Table 4).$^{71}$ Despite the distances,

69 David TUCKER, "France, Brossard Mopin, and Manchukuo", in Laura VICTOIR and Victor ZATSEPINE (eds), Harbin to Hanoi: The Colonial Built Environment in Asia, 1840 to 1940, Hong Kong: Hong Kong University Press, 2013, p. 59-81; Thomas CoOMANs, "Une utopie missionnaire? Construire des églises, des séminaires et des écoles catholiques dans la Chine en pleine tourmente (1941)", in Alexandre Tsung-Ming CHEN (ed.), Le christianisme chinois aux $19^{e}$ et $20^{e}$ siècles: figures, événements et missions-œuvres, Leuven: Ferdinand Verbiest Institute, 2015, p. 45-79.

70 Thomas Coomans, "Sinicising Christian Architecture in Hong Kong: Father Gresnigt, Catholic Indigenisation, and the South China Regional Seminary, 1927-31", Journal of the Royal Asiatic Society Hong Kong Branch 香港皇家亞洲學會學報, 56, 2016, p. 133-160. https://www.jstor.org/stable/jroyaaisasocihkb.56.133

71 Th. Coomans, "La création d'un style architectural sino-chrétien...” (see n. 2), p. 144-156. 


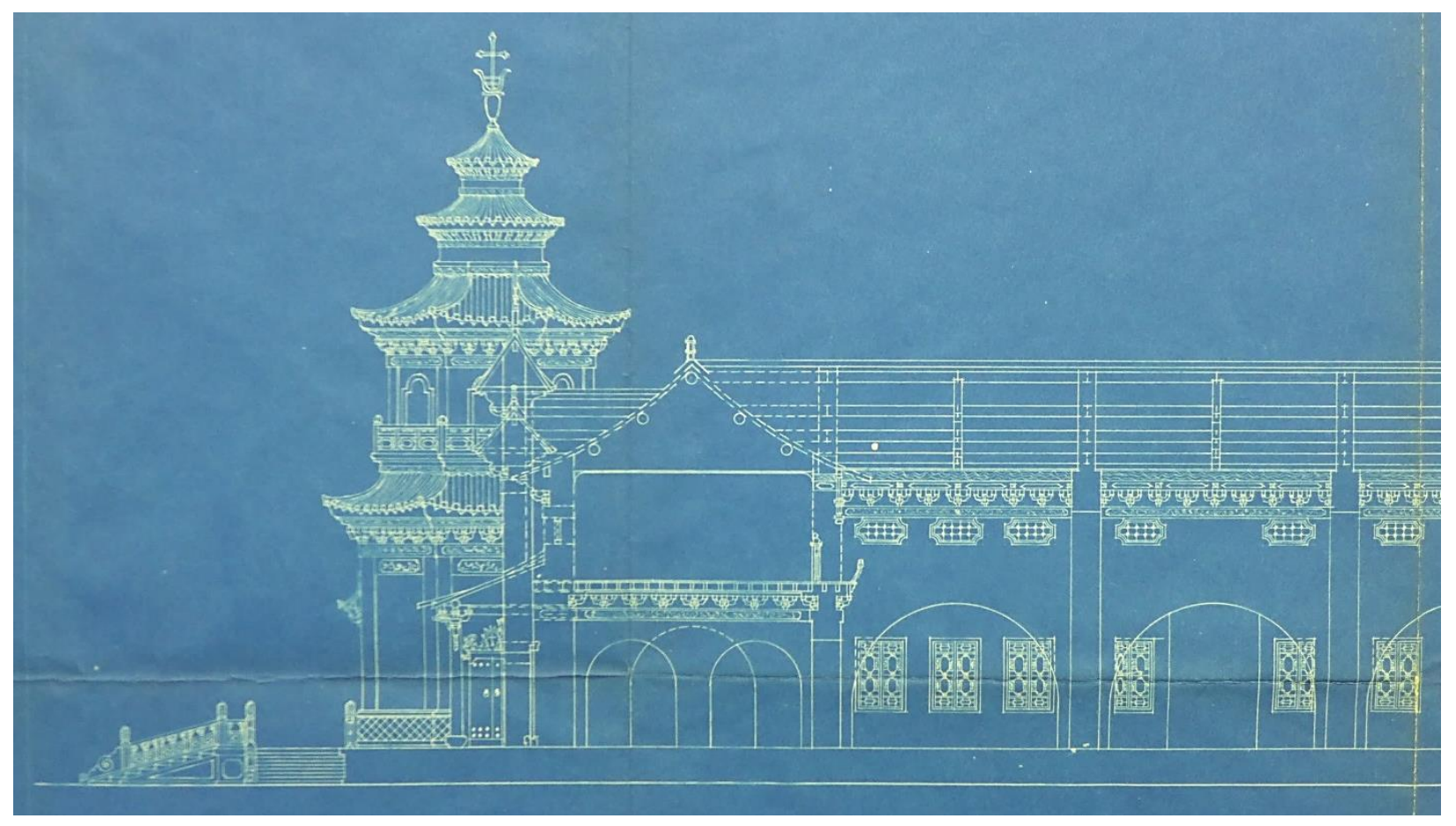

11. Haimen, unbuilt project for the cathedral of Mgr Simon Zhu Kaimin, Adelbert Gresnigt, ca 1930

(Archives of the Abbey of Maredsous).

financial issues and permanent instability, there was a great enthusiasm for the Chinese-Christian style, except in Hong Kong where Mgr Enrique Valtorta 恩理覺 (1883-1951) did his best to make it impossible, as a recent study has shown. ${ }^{72}$ Mgr Costantini eventually imposed his views, but the works remained incomplete due to the global economic crisis. In the British colony, strong resistance to the Sinicisation of Catholic church architecture came from the Portuguese parish congregations who believed only Western styles matched with their identity. When Father Gresnigt was asked to design two projects for the parish church of St Teresa in Kowloon - one Chinese, one Western one - the former was rejected and the latter realised by a Cantonese Catholic contractor. ${ }^{73}$ With the exception of the aforementioned cathedral of Mgr Sun in Anguo, Father Gresnigt designed another cathedral project for the Chinese [287] Jesuit Mgr Simon Zhu Kaimin 朱开敏 (1868-1960), vicar apostolic of Haimen (see Table 4). This beautiful project was never realised [Fig. 11].

Dom Gresnigt's short-term architectural achievements are remarkable, but would not have been possible without the support of Mgr Costantini and the networks mentioned above. The construction and opening of the university hall at the Catholic University of Peking on 1 October 1930 was given a high profile by Catholic propaganda worldwide and made Dom Gresnigt famous [Fig. 1]. Dom Pierre-Célestin Lou, who was a trustee of the Catholic University of Peking, undoubtedly celebrated

72 Th. CoOmAns, "Sinicising Christian Architecture in Hong Kong...” (see n. 70), p. 141-149.

73 Thomas CoOmans and Puay-peng Ho, “Architectural Styles and Identities in Hong Kong: The Chinese and Western Designs for St Teresa's Church in Kowloon Tong, 1928-32”, Journal of the Royal Asiatic Society Hong Kong Branch 香港皇家亞洲學會學報, 58, 2018, p. 81-109. https://www.jstor.org/stable/26531705 
this glorious moment from Saint-André, Bruges. ${ }^{74}$ Even the American architect Henry Murphy 亨利 - 墨菲 (1877-1954), [288] one of the pioneers of "adaptive architecture" in China and the designer of some iconic university campuses in Beijing, Nanjing and Changsha, ${ }^{75}$ asked to visit the building and came on 19 May 1931 "to confer with Dom Adelbert Gresnigt on the subject of Chinese Architecture". ${ }^{76}$ Paradoxically, it was at the peak of these great achievements that the American Cassinese Congregation began questioning its presence in China before withdrawing shortly afterwards for financial reasons, putting an end to Dom Gresnigt's plan to found a school of architecture at the Catholic University of Peking. Mgr Costantini no longer needed Dom Gresnigt in Beijing but did continue to promote his Sino-Christian-style buildings as archetypes of successful inculturated architecture. ${ }^{77}$

\section{REAL INCULTURATION: MORE THAN A QUESTION OF ARCHITECTURAL STYLES}

We do not know if Dom Adelbert Gresnigt met Father Alphonse De Moerloose in Beijing; if so, it would have been possible between May 1927 and December 1929. They would undoubtedly have disagreed on the issue of church architecture in China, which had been polarised by Mgr Costantini. On the one hand, Father De Moerloose, who belonged to the nineteenth-century generation of "colonial missionaries", was convinced of the universality of the Gothic style he had learned at St Luke and was deeply disappointed by the policy of the Apostolic Delegate. On the other, Dom Gresnigt played the part of a loyal agent in Mgr Costantini's game and was rewarded with international recognition.

Perhaps Father De Moerloose and Dom Gresnigt might have agreed on one subject, the abbey of Maredsous, and shared peaceful memories [289] of the beauty of the monastic liturgy in its remarkable church. Unfortunately, they would have soon argued about the aesthetic of the wall paintings that had been produced from 1882 onwards in the style of the Beuron Art School and Dom Desiderius Lenz, the master of Dom Gresnigt, by the German Benedictine oblate Andreas Weiss (1856-1937). Father De Moerloose, would have referred to his master, Baron Bethune, who believed

74 Bulletin of the Catholic University of Peking, 7, December 1930, p. 133.

75 Henry K. MuRPhy, "An Architectural Renaissance in China. The Utilization in Modern Public Buildings of the Great Styles of the Past", Asia, 28, June 1928, p. 468-475; Jeffrey W. CoDY, Building in Chine. Henry K. Murphy's "Adaptive Architecture" 1914-1935, Hong Kong: The Chinese University Press, 2001; J.W. CoDY, "American Geometries and the Architecture of Christian Campuses in China" (see n. 58), 2009.

76 Bulletin of the Catholic University of Peking, 8, December 1931, p. 155-156.

77 L'Art Chrétien Chinois: Dossiers de la Commission synodale/Digest of the Synodal Commission, 5, May 1932, p. 403-524 ; Albert GHESQUIERES and Paul MULLER, "Comment bâtirons-nous dispensaires, écoles, missions catholiques, chapelles, séminaires, communautés religieuses, en Chine ?", Collectanea Commissionis Synodalis, 14/2, February 1941, p. 1-80; Celso CostANTINI, L'art chrétien dans les missions, Paris-Bruges, 1949 , p. 205-221. 


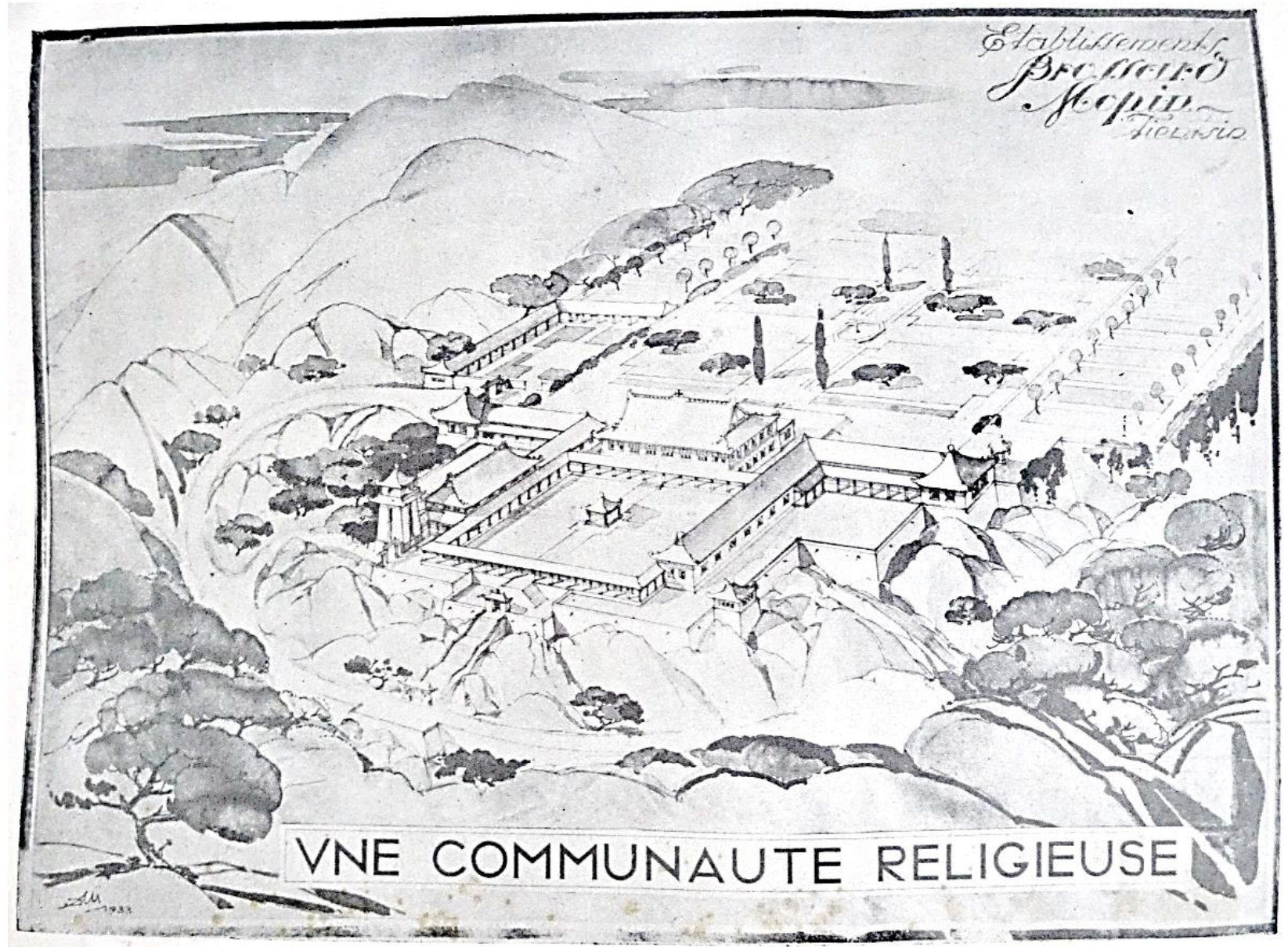

Fig. 12. Ideal project for a pilgrimage place operated by a religious community on a hill, 1933 (Collectanea Commissionis Synodalis, 1941, p. 74).

his architecture should be painted by Belgian St Luke artists after his Gothic drawings rather than in what he called the "Bavarian-Assyrian" style of Beuron. ${ }^{78}$ Here again, two different conceptions of art set architect De Moerloose and painter Gresnigt, as well as the monks of Maredsous, against each other. After completing his work in Maredsous, Weiss moved to the abbey of Saint-André in 1909 and worked on painting the church until his death in 1937. Dom Lou was thus ordained as a priest in 1935 by Mgr Costantini in a church with Beuron-style decoration. At the same time, Dom Gresnigt, who had abandoned both architecture and Sino-Christian art as soon he had left China in 1932, had resumed painting and was decorating the refectory of the Pontifical Holland College in Rome in the purest Beuron style. In 1940, he designed the tomb of Pope Pius XI in the Vatican grottoes.

78 About this serious conflict: D. Misonne, En parcourant l'histoire de Maredsous... (see n. 41), p. 123-130. On Andreas Weis: F. STANDAERT, L'école de Beuron... (see n. 59), p. 46-59, 104-105, 169-172. 


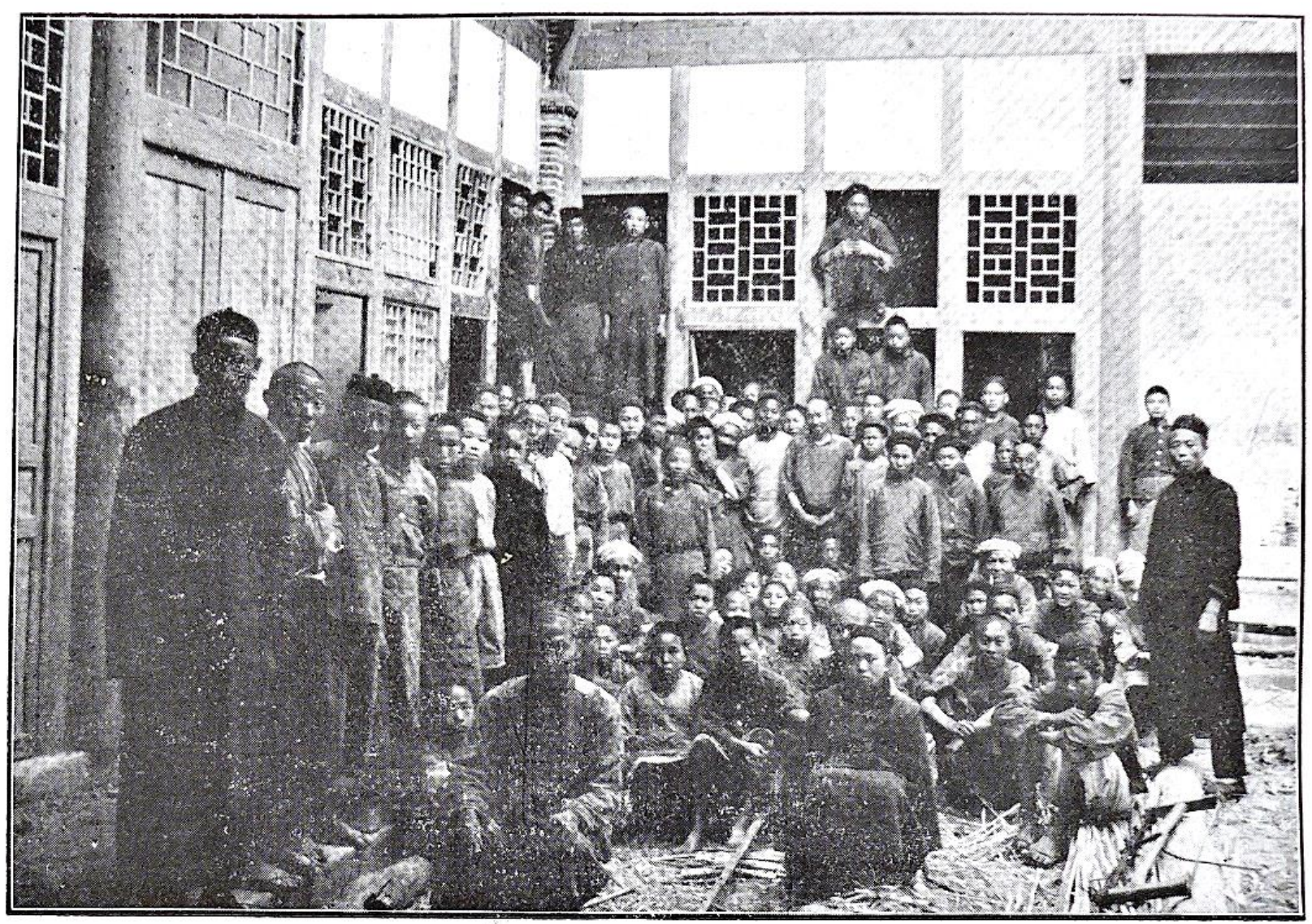

Fig. 13. Xishan, the local population helping in constructing the priory, 1929 (Courrier monastique chinois. Bulletin des Missions, September 1930, p. 12).

We have already argued elsewhere that the brief spell spent in China by Dom Gresnigt failed to generate truly inculturated architecture, but rather resulted in Western academic buildings with modern reinforced concrete structures covered with Chinese roofs and ornaments, i.e. "chinoiseries". ${ }^{79}$ The ideal design for a pilgrimage site operated by a religious community on a holy mountain 聖山, created in 1933 by Paul Muller, the French architect who drew up technical plans for Dom Gresnigt, is another example of "chinoiserie" [Fig. 12]. It was, however, published by the official journal of the Synodal Commission in 1941 among other models for post-war Catholic architecture. ${ }^{80} \mathrm{We}$ are in agreement with Dom Christian Papeians (1924-1981) and Father NicolliZani that the Priory of Xishan, built by local craftsmen following indications from Dom Jean Joliet, was the most [290] authentic inculturated Sino-Christian architecture and monastic experiment of its generation [Fig. 13]. ${ }^{81}$ "Today, we have to admit that the ideas of Dom Joliet were somewhat

79 Th. CoOmAns, "La création d'un style architectural sino-chrétien..." (see n. 2), p. 163-164.

80 A. GHeSQuiÈres and P. Muller, "Comment bâtirons-nous... » (see n. 77), p. 74-78; Th. CoOMAns, "Une utopie missionnaire?...” (see n. 69), p. 65-66.

81 Matteo Nicolini-ZANI, "The Monastery Will Be a Chinese House: The Inculturation of the Church in China from the Perspective of the History of Catholic Monasticism”, Religions \& Christianity in Today's China - e- 
prophetic; being Chinese with the Chinese, adapting the Benedictine rule to the Chinese mentality, accepting the Chinese ways and customs, preparing monks-priests to be ordained without any knowledge of Latin, all this was real "inculturation", long before the word began to be used. Neither Dom Nève nor Rome could be expected to acquiesce in this new understanding of the mission of the Church; such ideas were quite unknown before Vatican II". ${ }^{82}$ Several times Dom Joliet had dared to invite Buddhist monks to Xishan. Moreover, Dom Thaddeus Yang Anran 楊安然 (1905-82), an Indonesian-Chinese Buddhist convert who had been introduced to Saint-André by Father Lebbe and travelled with Dom Nève to Xishan, became the first Chinese Benedictine monk in history. He later moved to Saint Andrew's Abbey, Valyermo (California), and spoke of the complexity of his intercultural and interreligious experience. ${ }^{83}$

On the Protestant side, the most original attempt to Sinicise Christianity came in the form of Tao Fong Shan 道風山, a monastery on top of a hill at Shatin 沙田 in Hong Kong's New Territories, founded in 1930 by the Norwegian Lutheran missionary Karl Ludvig Reichelt 艾香德 (1877-1952) with the aim of stimulating encounters between Christianity and Buddhism. ${ }^{84}$ Architecture was an essential part of the project which had to fit into the long tradition of Buddhist mountain temples. The Danish architect Johannes Prip-Møller 艾術華 (1889-1943), who had studied the architecture of ancient Buddhist temples and published a reference book on the subject, [291] designed Tao Fong Shan as a modern Chinese temple-monastery complex in harmony with its site. ${ }^{85}$ All the buildings, including the temple-like eight-sided church, have concrete structures and Chinese forms. Both Xishan by Dom Joliet and Tao Fong Shan by Karl Reichelt were monasteries on remote hills, marginal experiments in cultural encounters and inculturation. It is worth noting that Dom Nève published an article on Tao Fong Shan in 1938, proving that Catholic monks could also take an interest in a ground-breaking Protestant-Buddhist project. $^{86}$

journal RCTC, 7/3, 2017, p. 41-53. The same in Chinese: NiCOLINI-ZANI, Matteo, 馬明哲, “'Yin xiu yuan jiang chengwei zhongguo zhi jia' cong tianzhujiao yin xiu shenghuo lishi de jiaodu kan jiaohui zai zhongguo de bendi hua”「隱修院將成為中國之家」從天主教隱修生活歷史的角度 看教會在中國的本地化”, Hong Kong Journal of Catholic Studies 天主教研究學報, 10, 2019, p. 223-240.

82 C. Papeians de Morchoven, "The China Mission of the Benedictine Abbey of Sint-Andries..." (see n. 28), p. 309. Also quoted in: M. Nicolini-ZANi, Christian Monks on Chinese Soil... (see n. 18), 2016, p. 212.

83 Thaddeus YANG, “The Chinese Adventure of an Indonesian Monk", Valyermo: Saint Andrew's Abbey 1971 https://www.saintandrewsabbey.com/category-s/82.htm (accessed 15 August 2020).

${ }^{84}$ Notto R. THELLE, "Karl Ludvig Reichelt," in Gerald H. ANDERSON et al. (eds), Mission Legacies: Biographical Studies of Leaders of the Modern Missionary Movement, Maryknoll: Orbis Books, 1994, p. 216-224.

85 Johannes PRIP-MøLlER, Chinese Buddhist Monasteries: Their Plan and its Function as a Setting for Buddhist Monastic Life 中原佛寺圖考, London: Oxford University, 1937; Johannes PRIP-MøLLER, “Architecture: A Servant of Foreign Missions", International Review of Mission, 28 1939, p. 105-115; Tobias FABER, Johannes Prip-Møller: A Danish Architect in China, Hong Kong: The Christian Mission to Buddhists, 1994.

86 Théodore NeVE, “Tao Fong-Shan”, Contemplation et Apostolat. Supplément au Bulletin des Missions, 17/1, June 1938, p. 1-5. The article does not include any discussion of architecture. 
In the 1920s and 1930s, the abbey of Saint-André had been at the forefront of a promising movement which was brutally interrupted by the Second World War, the Chinese Civil War and the death of Dom Lou in 1949. In the early years of the People's Republic of China, all foreign missionaries were expelled from China and the Benedictine monks eventually found new monastic stability in other abbeys (see Table 2). After a long Roman intermezzo, Father Gresnigt eventually returned to Maredsous in 1949 - which he had left in 1903 after his ordination - and passed away in 1956, two years before Mgr Costantini who had since become a cardinal. 